\title{
Havran jako kulturní fenomén
}

\author{
Barbora Půtová \\ Katedra teorie kultury (kulturologie) a Ústav pro dějiny umění Filozofické fakulty \\ Univerzity Karlovy v Praze, Celetná 20, 11000 Praha 1
}

\section{THE RAVEN AS CULTURAL PHENOMENON}

ABSTRACT The aim of this article is to deal with the analysis of raven as a phenomenon depicted within the fields of art, literature, music and native myths across the various cultural contexts. The main part contributes to the examination of raven symbolizing two different modalities since it is engaged as a symbol of death, evil and sin and on the other hand it serves as an image of cunning, trickery and prophecy. The final chapters follow the trace dominant in modern and postmodern culture, i. e. a figure of raven as an epitome of destruction. Suggesting a conceptual model, which would work as a platform for synthesis of numerous interpretations of raven is the main objective of this study.

KEY WORDS raven; culture; art; myth; literature; music

Havran představuje mytické, biblické a totemové ptactvo, které může vystupovat jako kulturní hrdina, posel bohů, moudrý rádce, pokušitel, nositel zla, hříchu nebo smrti. Způsob jeho interpretace a uměleckého ztvárnění se mění v závislosti na konkrétním kulturním okruhu.

V evropském kulturním areálu byl havran zpravidla považován za atribut a symbol hříchu, hereze, pohanství, lakomství a tvrdosti srdce. V křestanské ikonografii byl chápan jako negativní vtělení Žida nebo dábla unášejícího duši do temnot. Havran např́klad ztělesňoval dábla a neřest v protireformačním umění, kde byl vyobrazen zejména na letácích a pamfletech odsuzujících učení německého teologa a církevního reformátora Martina Luthera (1483-1546). Na dřevořezu Lutherova kacírská hra (1521) je Luther ztvárněn během vaření jako kuchař hříchu u velkého kotle v obklopení tří dáblů (obr. 1). Na rameni mu sedí havran a z kotle vycházejí různé druhy neřestí (pýcha, klam, závist, rouhání, kacířství aj.). Jiný středověký dřevořez ztvárňuje havrany na hlavách studentů v opozici k bílým holubicím. Havrani symbolizují „černou“, až nekalou tvorbu a bílé holubice „čistou“ tvorbu. Před studenty je u pulpitu posazen učitel s brýlemi na nose, ozbrojený metlou v pravé ruce (obr. 2).

Symbolika havrana má dlouhou literární tradici. Havran je zaznamenán již v nejstarším eposu světa Ša nagba imuru (doslova Toho, jenž v̌̌e zřel, Epos o Gilgamešovi). Zde vyslal Uta-napištim havrana, který spatřil opadávající vody a již se nevrátil (Epos o Gilgamešovi 1958, 145):
„Havrana jsem vyslal a volně pustil.

Vylétl havran a spatřil opadávající vody.

Hledá, poletuje, kráká, zpět se však nevrátil."

Inverzní motiv je zaznamenán ve starozákonní knize Genesis (v současné podobě vznikla přibližně až v 5 . nebo ve 4 . století př. n. 1.). Noe vypustil čtyřicet dní po potopě havrana, který vylétával a vždy se vracel do archy (Genesis 8,6-7). Havran je považován za ptáka schopného lidské řeči, jehož charakterizuje věštění a prorokování. Havrani byli dokonce ochočováni a učili se fráze, jež opakovali. K jejich charakteristickým znakům se proto řadila i učenlivost, chytrost a žvanivost, stejně jako lenost, hříšnost a neřest. Havrana pohlížejícího do knihy zachytil německý malír Carl Spitzweg (1808-1885) na obraze Havran (kolem 1840) (obr. 3). Havran byl dokonce personifikací dvou ze sedmi kardinálních hříchů - nestř́ídmosti (gula) a lakoty (avaritia). Spojení havrana s temnou neřestí a hř́šnými vášněmi podpořil i latinský filozof a teolog Aurelius Augustinus (354-430), který jej označil za symbol světského umění. Na obraze Svět naruby (1663) nizozemský malír Jan Havickszoon Steen (1662-1679) zachytil havrana v kontextu neřestného světa, $v$ němž věci a osoby postrádají obvyklý řád (obr. 4). V mnoha literárních a výtvarných dílech se setkáme $s$ přesvědčením, že havran poskytuje svou podobu čarodějům a vedle kočky nebo sovy doprovází čarodějnice, jak dokládá např́klad heliogravura Př́prava na sabat (Malá čarodějnice II.) belgického malíre a grafika Féliciena Ropse (1833-1898). 


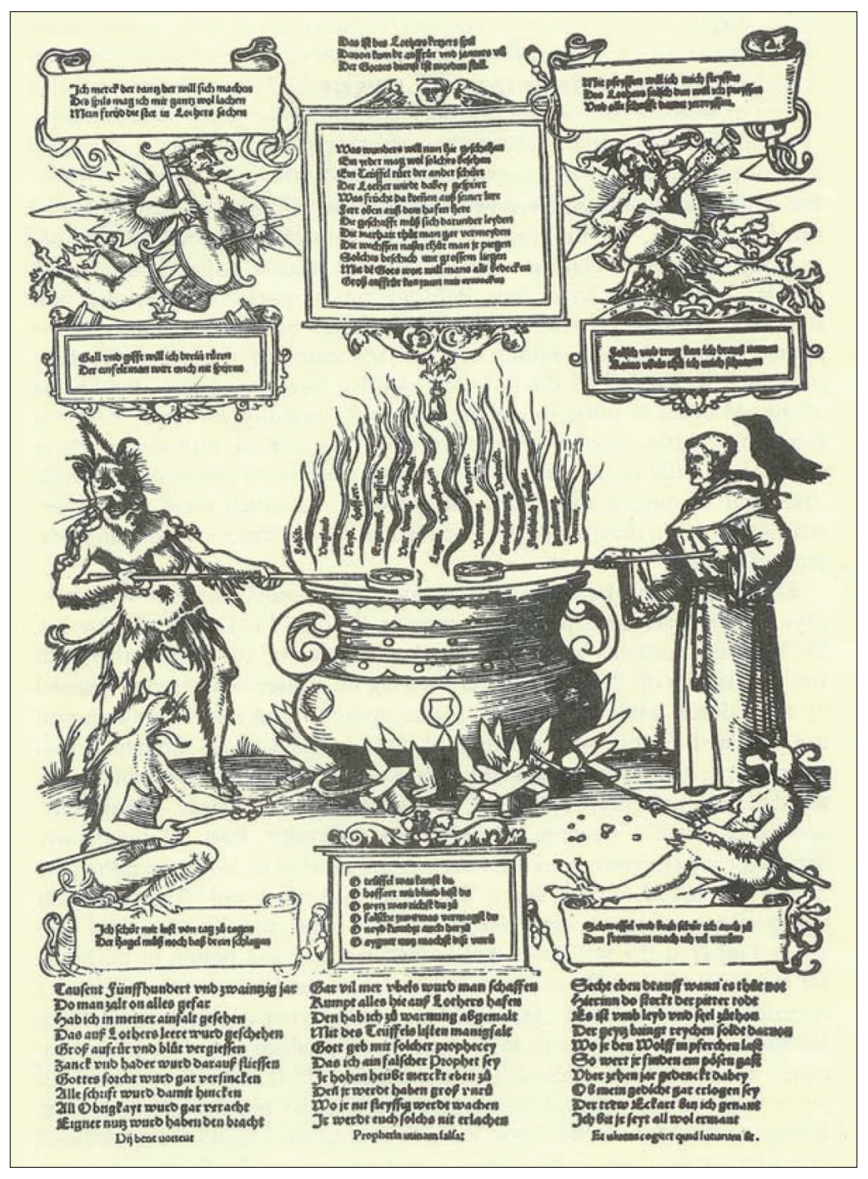

Obr. 1. Lutherova kacírská hra, dřevořez (1521).

Zde čarodějnice sedí v budoáru před toaletním stolkem (obr. 5), kde si štětečkem nanáší pudr na obličej. Nánosy pudru sleduje v malém přenosném zrcátku, za nímž je na stolku opřeno další oválné zrcadlo. Čarodějnice má bílé punčochy, tmavou pelerínu a čepeček, připevněný na dlouhých světlých vlasech. Na podlaze se nachází nejenom zobrazení havrana, nýbrž i koštěte, sloužícího k letu na sabat.

Havran údajně dokázal zprostředkovávat vnuknutí básníkům, učencům i léčitelům. Navíc oznamoval nemoci, válku a smrt. Nositelem negativních vlastností havrana bylo také peří, jehož odlesk se mění na škále černé, kovově modré až fialové a metaforicky označuje temnotu. Navzdory těmto negativním konotacím jsou ovšem ve starozákonní knize Píseň písní $(5,11)$ krásné kadeře milého přirovnány k černému peří havrana (kniha byla sestavena ze starších pramenů nejspíše až v 5. století př. n. 1.).

V antickém Řecku se vyskytuje motiv podvedeného a zahanbeného havrana, který uvedl do svých bajek Havran a liška nebo Havran a páv starořecký bajkář Ezop (přibližně 6. století př. n. 1.). V bajce Havran a liška dostala liška chut na sýr, který držel havran v zobáku. Lstivá liška vyjádřila smutek nad tím, že nikdo neslyší havranův hlas. Havran, který se chtěl pochlubit svým zpěvem, otevřel zobák, $\mathrm{z}$ něhož mu vypadl kousek sýra (Ezop 1975, 22): „... a lišák už jej držel. Dodá jízlivě: ,Ach nejsi němý, zvučný hlas máš, havrane! Máš všechno možné, všechno - jenom rozum ne. "V rukopisu arabských bajek Kalila wa

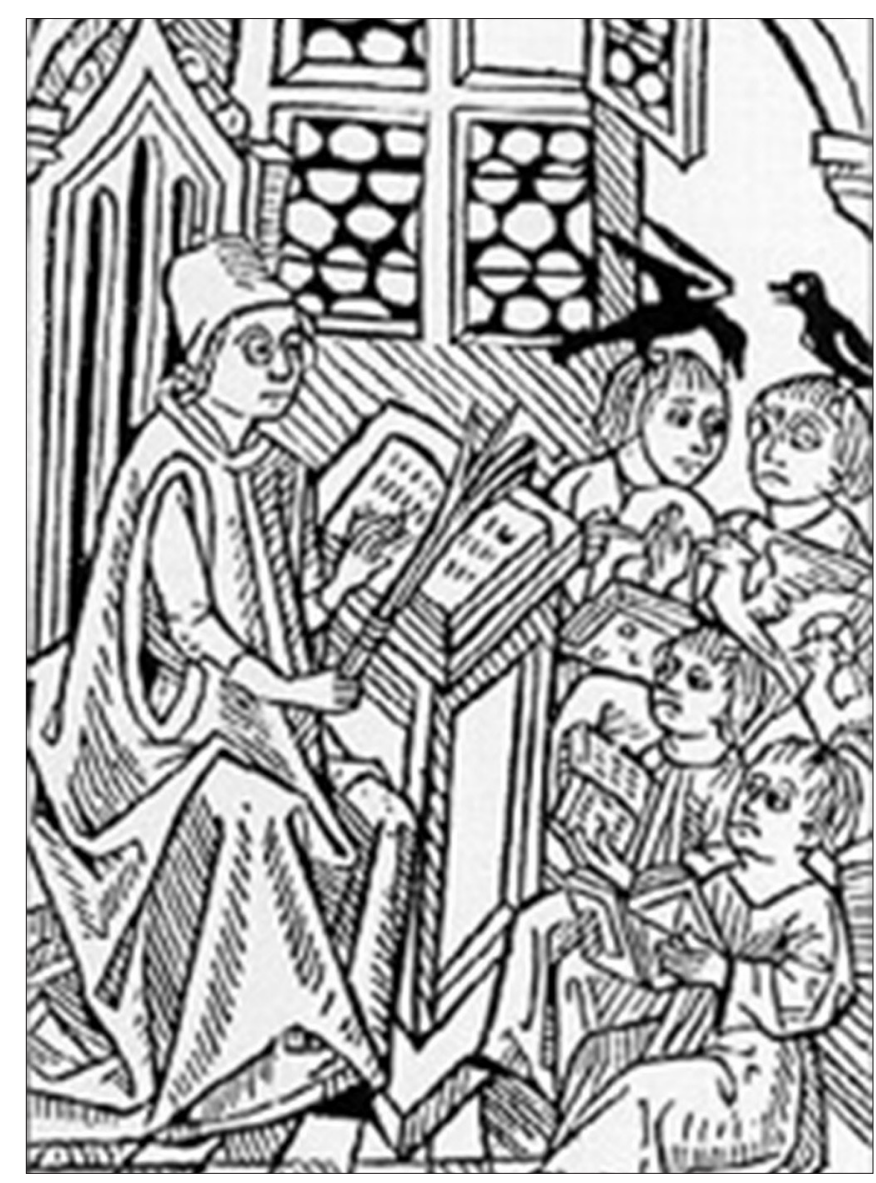

Obr. 2. Středověký dřevořez.

dimna (Kalíla a Dimna, originál překladu kolem roku 1210), který byl vytvořen kolem roku 1350, je provedena iluminace havrana a lišky. Havran stojí čelně k lišce, jejíž tlamička je rozevřená a připravena zmocnit se lahodného sýra (obr. 6). Bronzové skulptury Havran a liška (1974) vytvořil německý sochař Karl-Heinz Goedtke (1915-1995) v okamžiku, kdy havran rozevírá svůj zobák (obr. 7). V bajce Havran a páv se havran zdobil pery páva a opovrhoval jinými havrany. Pávi se rozhorlili, začali vyklovávat cizí peří a téměř ho uklovali. Havran se styděl vrátit mezi havrany. Svou hanbu a opovržení si mohl ušetřit, kdyby zůstal spokojen ve svém ošacení. Nizozemský malír Melchior D’Hondecoeter (1639-1695) na plátně Svlékání vypůjčeného peří umělecky ztvárnil motiv, kdy ptáci vyklovávají havranovi cizí peří (obr. 8).

$\mathrm{V}$ antické mytologii vystupuje havran jako průvodce a atribut boha Slunce Apollóna, který poslal havrana pro pohár vody určené jako obět Diovi. Havran cestou spatřil strom s nezralými fíky a mlsně setrval, dokud nedozrály. Teprve poté splnil úkol. Př̀i setkání s Apollónem tvrdil, že se opozdil kvưli vodní nestvůře Hydře, která mu bránila nabrat do poháru vodu. Bůh ovšem prohlédl lež a havrana potrestal věčnou žízní. Havrana umístil na oblohu hned vedle Poháru. V uhašení žízně mu však brání Hydra, která se nachází mezi havranem i Pohárem. Jeho krásný hlas nahradilo drsné krákání, vycházející ze suchého hrdla. Řecký astronom, matematik a geograf Klaudios Ptolemaios (kolem 85-kolem 165) 


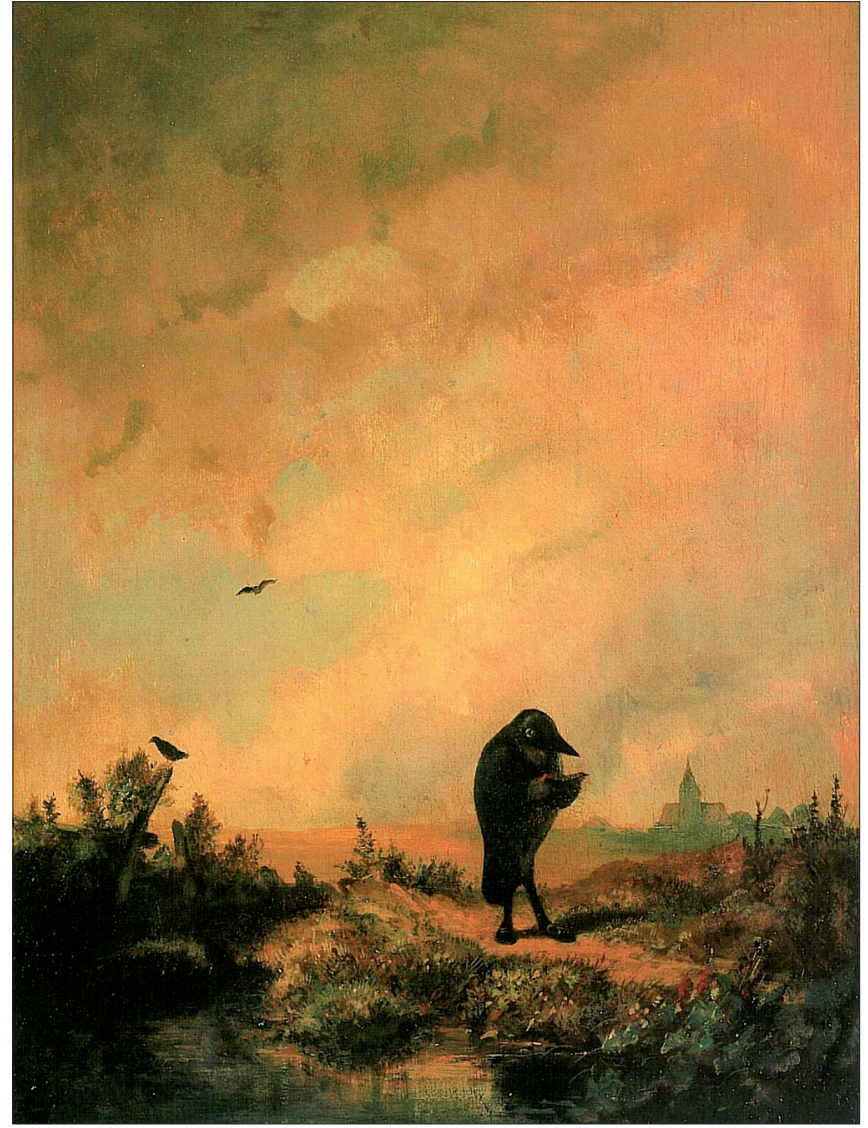

Obr. 3. Německý malír Carl Spitzweg (1808-1885), olejomalba Havran (kolem 1840)

stanovil havrana jako jedno ze 48 souhvězdí na jižní obloze. Ř́mský básník Publius Ovidius Naso (43 př. n. 1.-17 nebo 18 n. 1.) v díle Metamorphoseon libri (Proměny, kolem roku $8 \mathrm{n}$. 1.) zaznamenal havranovo vyzrazení nevěry oblíbenkyně Apollóna - krásné Korónis z města Lárissy. Apollón ji za trest proklál šípem, litoval svého činu a havrana zavrhl. Havrani, kteří byli původně sněhově bílí, získali poté černé peří. $\mathrm{V}$ havraní podobě vedl Apollón obyvatele ostrova Théry (Santorini) na severní pobřeží Afriky, kde založili kolonii Kyréné.

$\mathrm{S}$ havranem se nesetkáváme pouze $\mathrm{v}$ antické mytologii, ale také ve vojenské námořní terminologii. Na římských válečných lodích slovo havran (corvus) sloužilo k označení dlouhého padacího můstku, jenž se spouštěl prostřednictvím kladky, umístěné na vrcholu vysokého stožáru. Havran, skládající se ze sklápěcí části, byl otočný kolem osy stožáru. Během plavby se jeho sklápěcí část zdvihala a vztyčená v horní poloze se uvazovala. Ve chvíli bojového střetu s cizí lodí byl havran sklopen na nepřátelskou lod, jejiž palubu prorazil železným zobcem. Toto zachycení umožnilo vojákưm přeběhnout po můstku na lod' a zmocnit se jí.

Originálním způsobem vstoupil motiv havrana a s ním spojovaná symbolika do židovské a křestanské kultury. V bibli se setkáváme dokonce s havrany, kteří prokazují i dobré skutky a stávají se symboly božské osamocenosti. Napríklad havran přinesl starozákonnímu proroku Eliášovi na poušt potravu (1 Královská 17,4). Setkání havrana s Eliášem umělecky ztvárni-

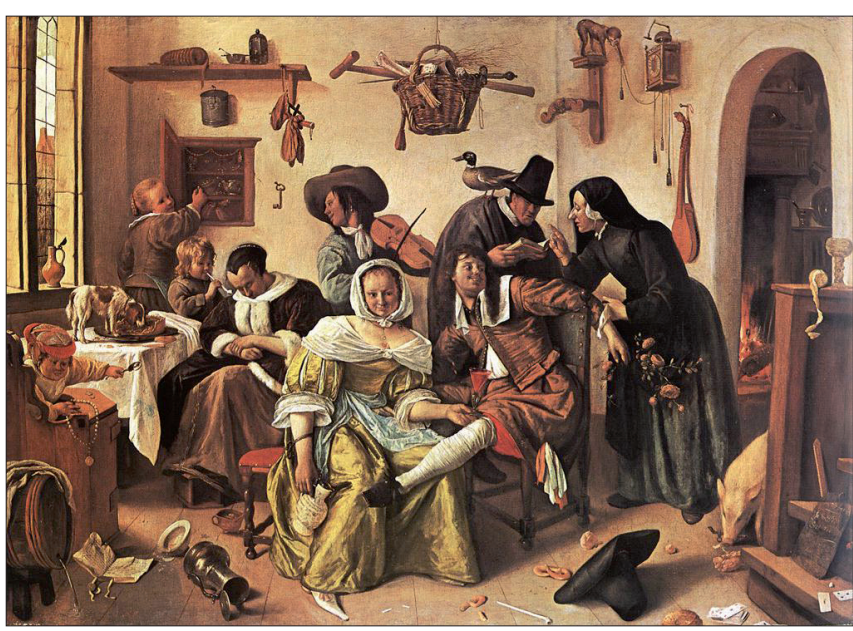

Obr. 4. Nizozemský malíř Jan Havickszoon Steen (1662-1679), olejomalba Svět naruby (1663).

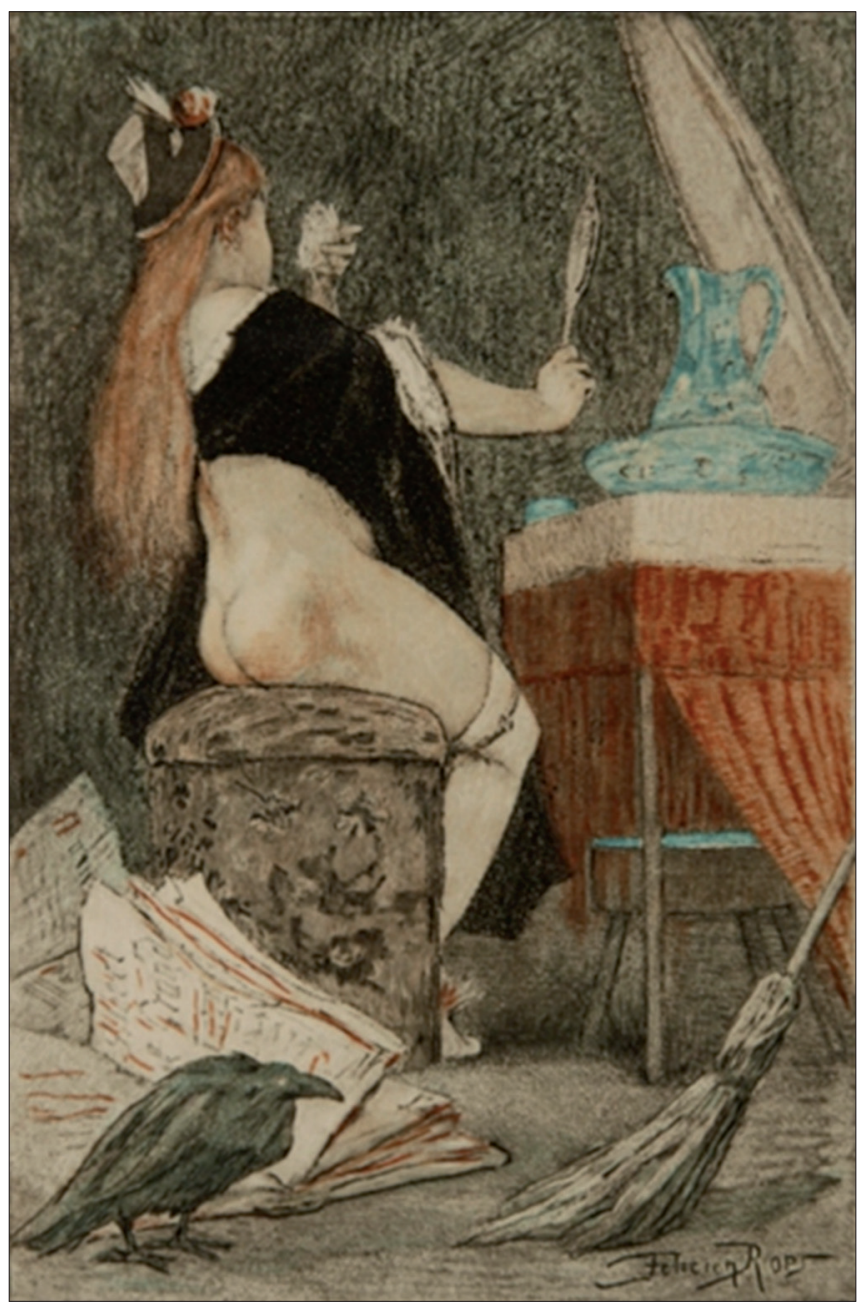

Obr. 5. Belgický malír a grafik Félicien Rops (1833-1898), heliogravura Př́prava na sabat (Malá čarodějnice II.).

lo několik italských malî̌ru, jako např́íklad Giovanni Girolamo Savoldo (1480-1548) na obraze Eliáš krmený havranem (kolem 1510) nebo Guercino (1591-1666) na plátně Eliáš krmený havranem (1620). Havran přinášel potravu, zpravidla chléb, 


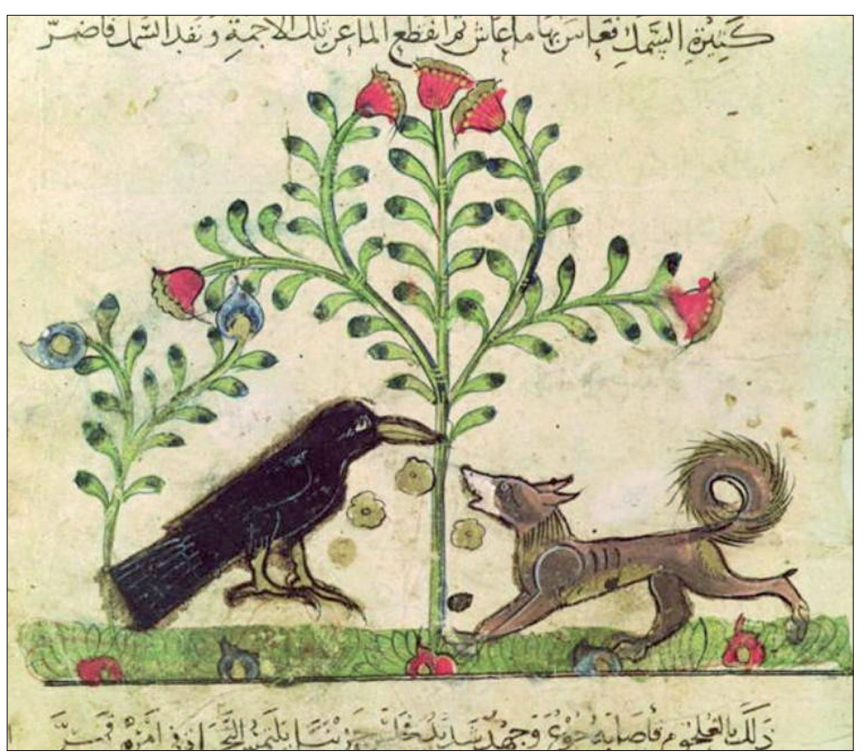

Obr. 6. Rukopis arabských bajek Kalila wa dimna (Kalíla a Dimna, kolem roku 1350).

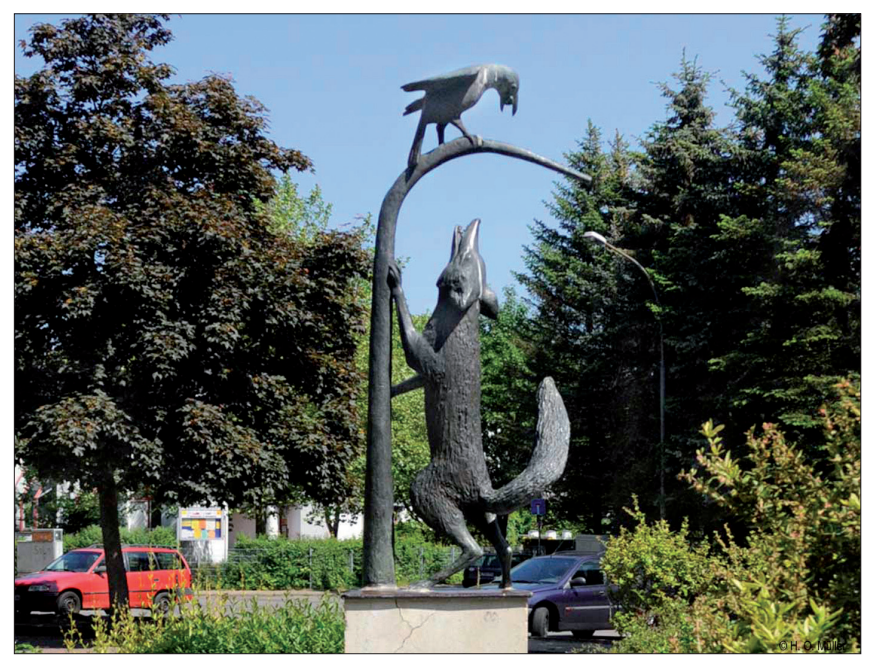

Obr. 7. Německý sochař Karl-Heinz Goedtke (1915-1995), bronzové skulptury Havran a liška (1974).

i svatým poustevníkům - Erasmovi (zemřel kolem 303), Antonínu Velikému (kolem 251-356) nebo Pavlu Poustevníkovi (Pavlu Thébskému, 3.-4. století). Španělský barokní malír Diego Rodrígues de Silva Velázquez (1599-1660) zachytil havrana na olejomalbě Svatý Antonín Veliký a Pavel Poustevník (1635-1638) v okamžiku, kdy slétá z nebe se skývou chleba k modlícím se světcům (obr. 9). Tyto dva světce, k nimž přilétá havran, ztvárnil i německý malír a grafik Matthias Grünewald (kolem 1475/1480-1528) na polyptychu Isenheimský oltář (1512-1516) (obr. 10). Havrani se dokonce stali atributy některých křestanských světců, $\mathrm{k}$ nimž patří například Onufrius Veliký (kolem 320-kolem 400), Benedikt z Nursie (kolem 480-547), Bonifác (673-754), Osvald (kolem 604-642) a Meinrad (zemřel 861). Tento světec vlastnil dva ochočené havrany, kteří podle jedné legendy pomohli najít jeho tělo a podle druhé pronásledovali jeho vrahy až do Curychu. Světec a zároveň král severní Umbrie (pomezí Anglie a Skotska) Osvald

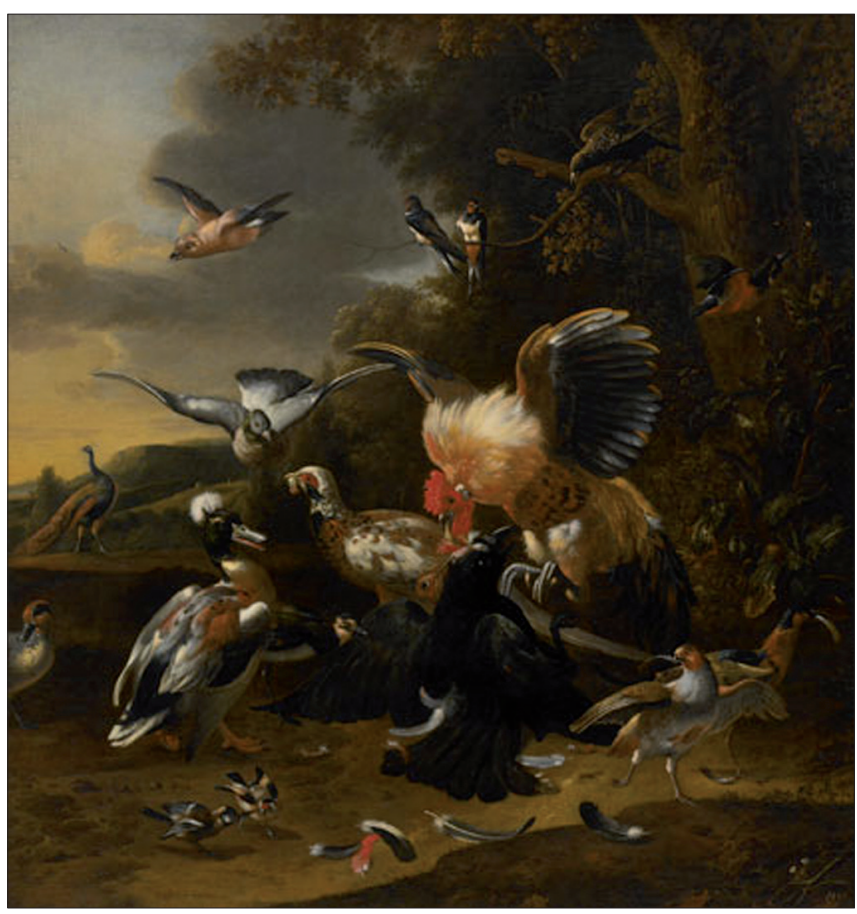

Obr. 8. Nizozemský malír Melchior D’Hondecoeter (1639-1695), olejomalba Svlékání vypůjčeného peř́.

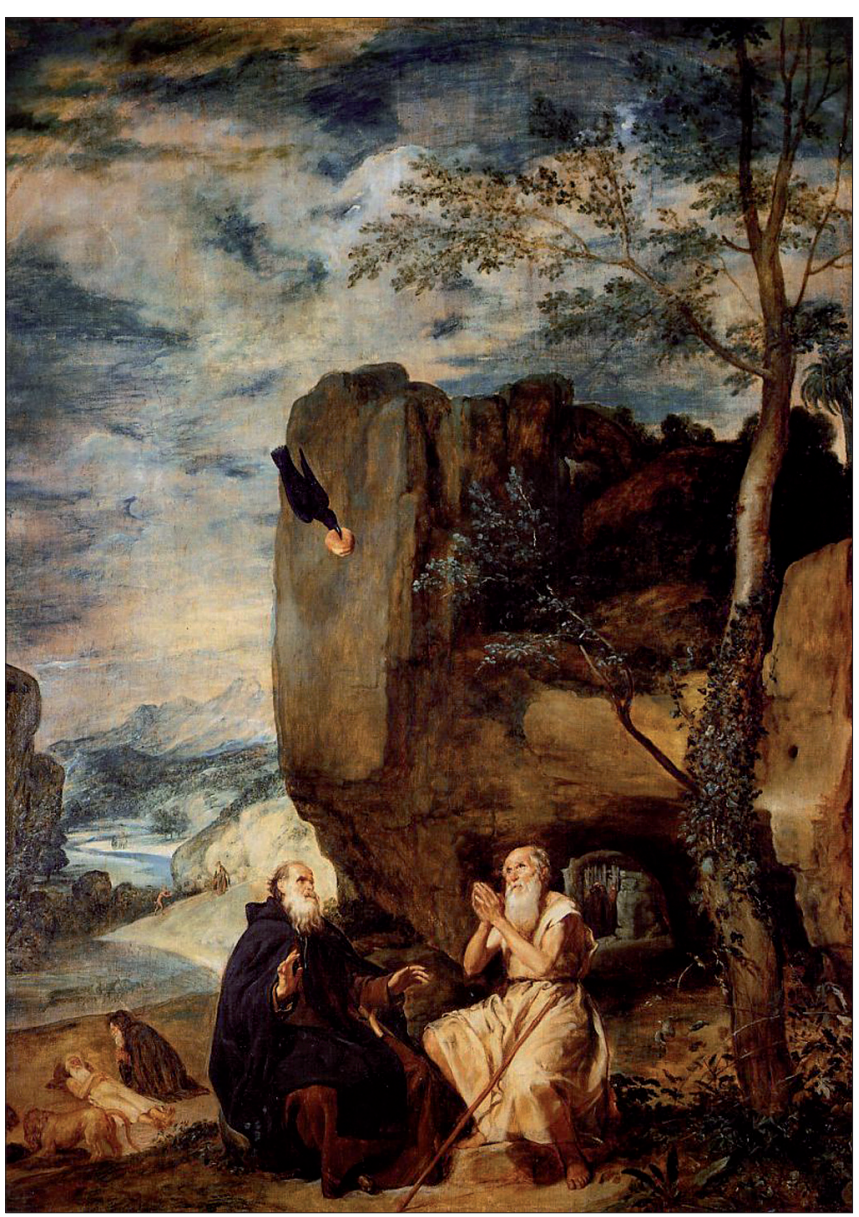

Obr. 9. Španělský barokní malír Diego Rodrígues de Silva Velázquez 1599_ 1660), olejomalba Svatý Antonín Veliký a Pavel Poustevník (1635-1638). 


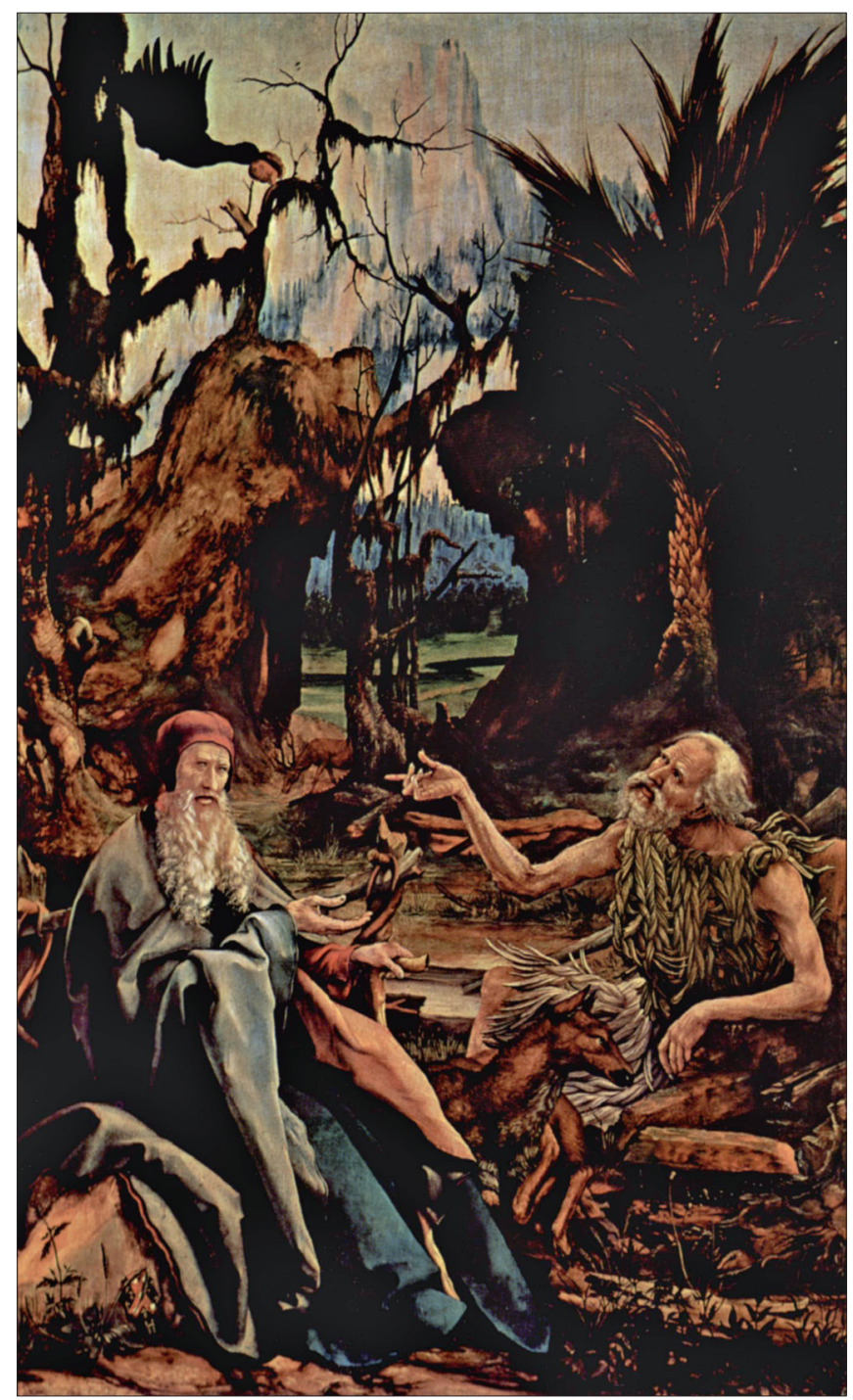

Obr. 10. Německý malír a grafik Matthias Grünewald (kolem 1475/14801528), polyptych Isenheimský oltár (1512-1516).

vlastnil havrana, jenž vylétal s prstenem v zobáku jako námluvčí. Ojediněle je havran zachycen i na mariánských obrazech, kde symbolizuje prríchozí zlo a smrt v podobě Kristova utrpení a smrti na kř́ži. V koruně uschlého stromu je usazen za ztvárněním Madony s dítětem na obraze Madona na louce (1505), jejímž tvůrcem je italský malír Giovanni Bellini (1430-1516) (obr. 11). Havran jako neodbytný hlasatel smrti, nepřítel muže, jehož prozradí v útěku před ženou, vystupuje ve filmu Antichrist (Antikrist, 2009), jehož autorem je dánský filmový režisér Lars von Trier (narozen 1956).

Lidi na havranovi nefascinoval pouze tvar těla a barva jeho peří, nýbrž i zvuky, které byl schopen vydávat. Například anglický františkán Bartholomaeus Anglicus (před rokem 1203po roce 1250) v encyklopedii De proprietatibus rerum (O vlastnostech věcí, kolem 1240) havranům přisoudil čtyřiašedesát různých hlasů. Přriškrcený hlas havrana údajně vyjadřuje neštěstí nebo špatnou zprávu, jejíž význam si havran uvědomuje. Havraní hlas charakterizuje hluboké „kráá-kráác, „kro“ nebo krátké „gag“. Interpretace zvuků, které havran vydává, ovšem



Obr. 11. Italský malír Giovanni Bellini (1430-1516), olejomalba Madona na louce (1505).

závisí na časovém úseku, v němž lidé krákání zaslechnou. Havraní krákání v průběhu osmé až desáté hodiny večerní vyjadřuje radost, zatímco v následujících dvou hodinách již ohlašuje smrt. Motiv havrana jako symbolu smrti a zániku pronikl z židovsko-křestanské literatury dokonce do islámské kultury. V koránu, který je základem islámského myšlení, havran přilétá ke Kainovi a radí mu, jak ukrýt mrtvolu svého bratra Ábela. Kain ovšem běduje, nebot’ není schopen být ani jako havran, a pronásledují ho výčitky svědomí (5:31).

Vztah havrana a smrti byl posílen jeho záměnou s krkavcem, který přilétal na bitevní pole a popraviště, kde se živil mršinami. Havran doprovází i ikonografická zobrazení Kristova ukřižování na Golgotě, jako je tomu na obraze Nesení kř́že (1564), jež ztvárnil nizozemský malíř Pieter Bruegel starší (kolem 1525-1569) (obr. 12). Anglosaská skladba Béowulf (750-950) představuje havrana jako toho, který se spolu s vlkem slastně sytí sápáním těl (řádek 3024-3027). Ve skladbě Ortulus phizologye (Zahrádka fyziologie, 1365, vydáno pod názvem Physiologiarius) český učenec, lékař a lexikograf Bartoloměj z Chlumce (kolem 1320-1370/1379), zvaný Klaret, uvedl, že havran pojídá mršiny a ke svým mládatům se hlásí až třetí den po narození (Claretus 1991, 25): „... když pak třetího dne vidí, že černají, začne je krmit, nebot' poznal, že jsou jeho vlastní. " Rímský př́rodovědec a filozof Gaius Plinius Starší (23-79 n. 1.) v encyklopedicky koncipovaném spisu Naturalis historia (Př́rodopis, 37 knih) napsal, že havrani snášejí vajíčka zobákem. Z tohoto důvodu by se těhotná žena měla vystř́hat konzumace nebo uchování vajec ve svém domě, jinak bude mít obtížný porod. Latinský teolog, historik a kronikář Isidor ze Sevilly (kolem 560-636) ve dvanáctém svazku díla Etymologiarum sive originum libri XX (Etymologie čili počátky) uvádí, že havran vyklove z mrtvol nejdříve oči, čímž destruuje duševní schopnosti a úsudek. Havran požírající mrtvolu zároveň reprezentuje krásné a nebezpečné válečnice valkýry, jež na bitevních polích vybírají duše padlých válečníků. Dialog havranů a valkýry obsahuje báseň Hrafnsmál (Havraní píseň), jejímž autorem je norský skald 


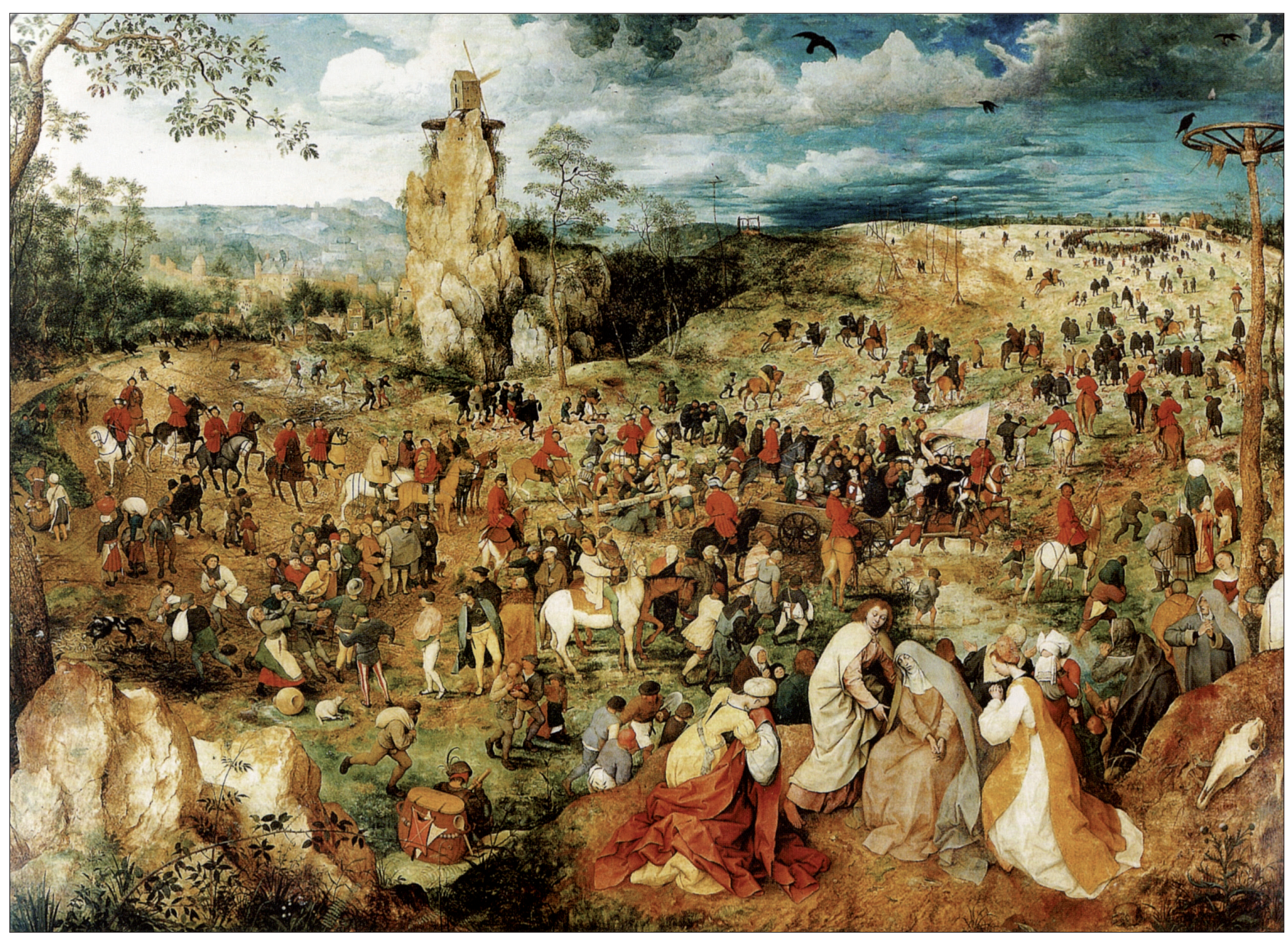

Obr. 12. Nizozemský maliř Pieter Bruegel starší (kolem 1525-1569), olejomalba Nesení kř́že (1564).

Torbjörn Hornklofi (9. století). Valkýra se na začátku básně táže havranů, odkud přilétají brzy zrána s krvavými a mrtvolně páchnoucími zobáky. Havrani dále pějí chvalozpěv na norského krále Herolda Krásnovlasého (kolem 852-933), kterého údajně doprovázejí od chvíle svého vylíhnutí z vejce, a jeho vítězství v bitvě u Hafrsfjordu (872). Důvěrné setkání havrana a valkýry zachytil britský malír a ilustrátor Anthony Frederick Augustus Sandys (1829-1904) na grafickém listu Valkýra hovořicí s havranem (1862) (obr. 13).

S mrchožravostí, všežravostí a kategorií nečistého spojovala havrana i židovská kultura, jež považuje havrana za trejfe pokrm (Leviticus 11,15; Deuteronomium 14,14). Kromě všežravosti jsou havrani spojováni i se zlodějstvím. V německy hovořících zemích dokonce zloději nekradou jako straky, nýbrž jako havrani (stehlen wie die Raben). Na Islandu se dětem rríká, že nemají používat havraní brko jako brčko k pití, jinak z nich vyrostou zloději. Výchovné poselství havrana posiluje i biblické poučení, že havrani vyklovou oko, které se vysmívá otci a pohrdá poslušností k matce (Přísloví 30,17). Možná $\mathrm{z}$ důvodu převažujících negativních konotací evangelium na havranech dokládá, že každá živá bytost je zabezpečena bez ohledu na zásluhy. Havrani totiž ani nesejí, nežnou, nemají komory ani stodoly, a přece je Bůh živí (Lukáš 12,24).
Motiv havrana byl zachycen i v orientálních mytologiích a pohádkách na Dálném východě. Například ve starověké Číně byl ztotožňován se Sluncem. Podle jedné z legend porodila sluneční bohyně deset synů - havranů. Ti vystoupili na oblohu a zemi postihlo sucho a vedro. Teprve když nebeský lukostřelec Chou-i sestř̌elil devět Sluncí, pocítila země úlevu. Poslední Slunce, které zemi i lidem slouží k užitku, ušetřil lukostřelec údajně na rozkaz císaře Jaoa. Havran se poté stal poslem Královny matky Západu Si-wang-mu. V období vlády čínské dynastie Čou (1027-256 př. n. 1.), která se také ztotožňovala se Sluncem, byl jako symbolické zvíře uctíván červený havran. Již na nejstarších kamenných reliéfech je havran ztvárněn jako zvíře Slunce, jemuž tvoři protějšek zajíc, zvíre Měsíce. V čínském kulturním areálu jsou havrani považováni za oddaná zvířata. $Z$ tohoto důvodu docházelo $\mathrm{k}$ jejich ztvárnění na náhrobcích mužů, kteří se vyznamenali svou oddaností (siao).

Havrani v roli hypostaze božstva vystupují také v keltské a germánské mytologii. Podle jednoho z mýtů pravidelně za úsvitu vylétali havrani Hugin (Myšlenka) a Munin (Vzpomínka) do světa (Edda 1962, 89): „Hugin a Munin každý den musí oblétnout obzor." Navraceli se ke snídani a usedali na ramena germánskému bohu válek a smrti Odinovi. V jejím průběhu 


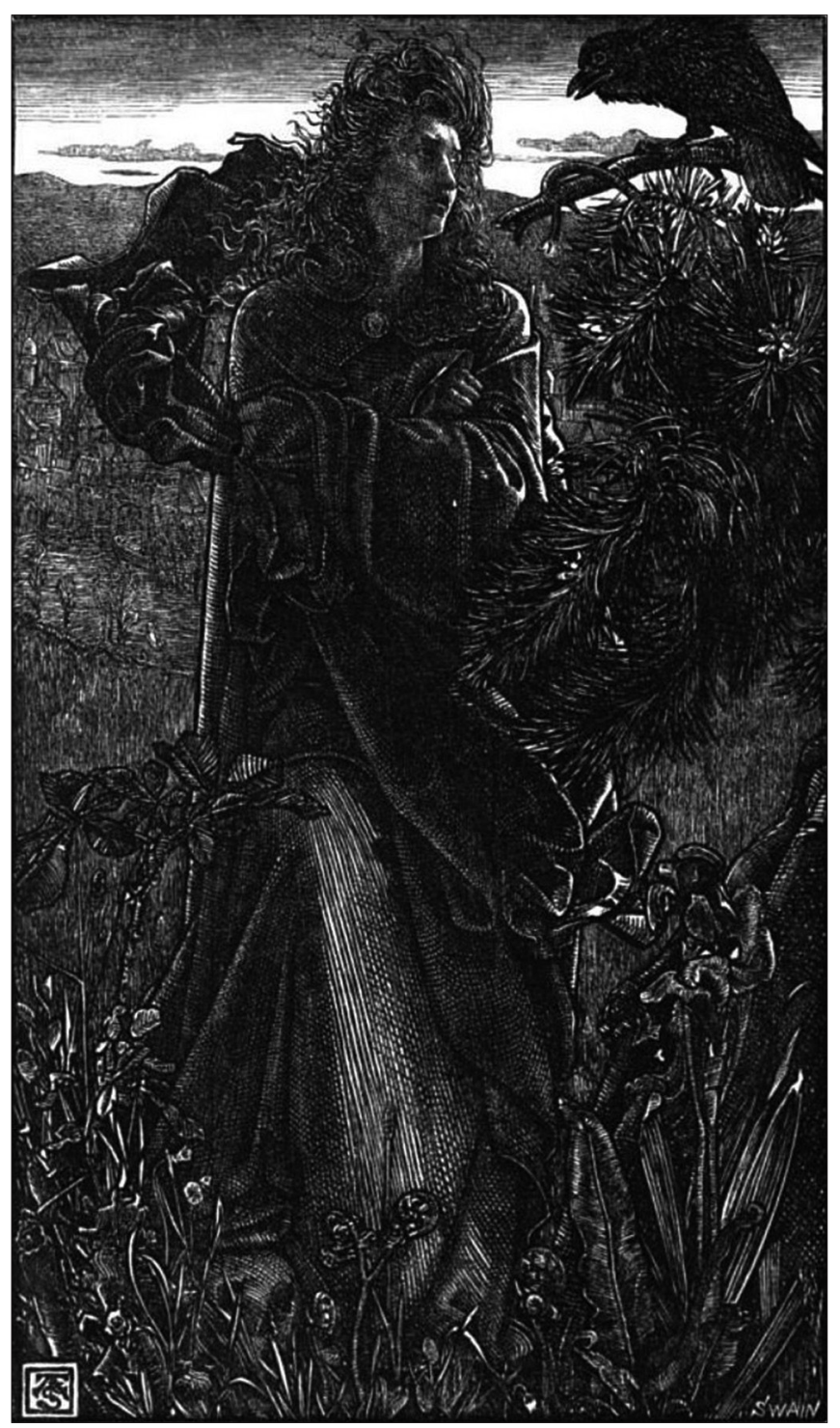

Obr. 13. Britský malír a ilustrátor Anthony Frederick Augustus Sandys (1829-1904), grafický list Valkýra hovořící s havranem (1862).

našeptávali a sdělovali Odinovi vše, co zaslechli a spatřili. Stejně přinášeli zprávy keltskému bohu světla Lugovi. Samotné pojmenování Lug označuje i havrana s černým peřím. Řecký spisovatel Plútarchos (kolem 50-120) předpokládá, že jméno boha je odvozeno od původně keltského označení pro havrana (v nářečí keltských Allobrogů „lug“).

Jako nositelé zpráv a př́telé jsou havrani prezentováni v knize The Hobbit or There and Back Again (Hobit aneb Cesta tam a zase zpátky, 1937), kterou, inspirován germánskou a keltskou mytologií, napsal britský spisovatel a filolog John Ronald Reuel Tolkien (1892-1973). Havrany charakterizuje dobrá pamět', dlouhověkost a mezigenerační kontinuita moudrosti. Bilbo se na cestě $s$ trpaslíky a jejich vůdcem Thorinem setkává s prastarým ohromným havranem, jenž k výpravě promlouvá (Tolkien 1979, 311-312): „Je to už sto a tríiapadesát let, co jsem se vyklubal z vajícka, ale nezapomínám, co mi kdy otec pověděl." V mystériích íránského boha Mithry vyjadřuje havran první stupeň zasvěcení (Corax) ze sedmi. Počtu stupňủ odpovídá

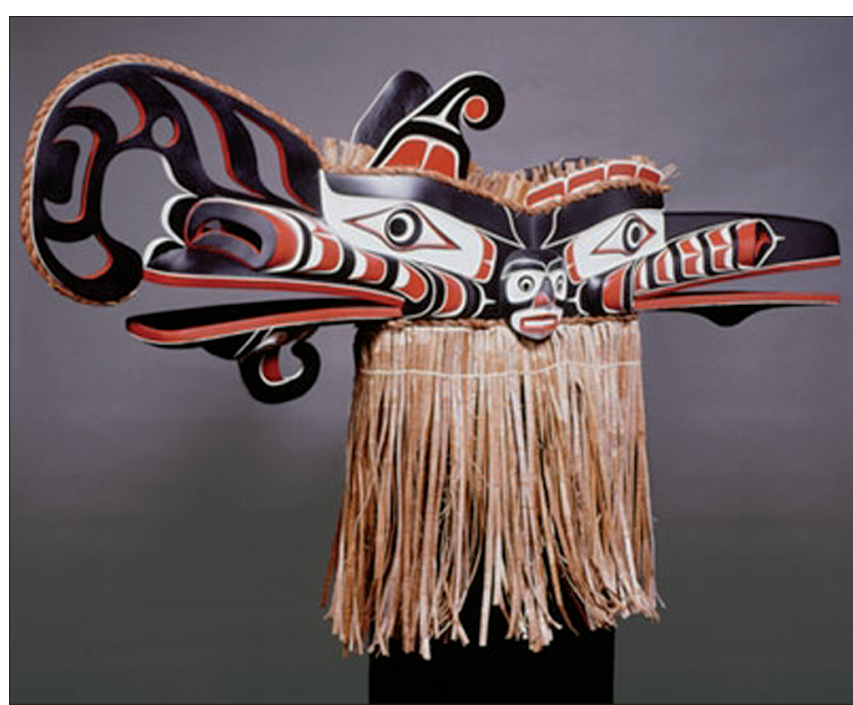

Obr. 14. Maska havrana, kwakiutlská tajná společnost Hamatsa.

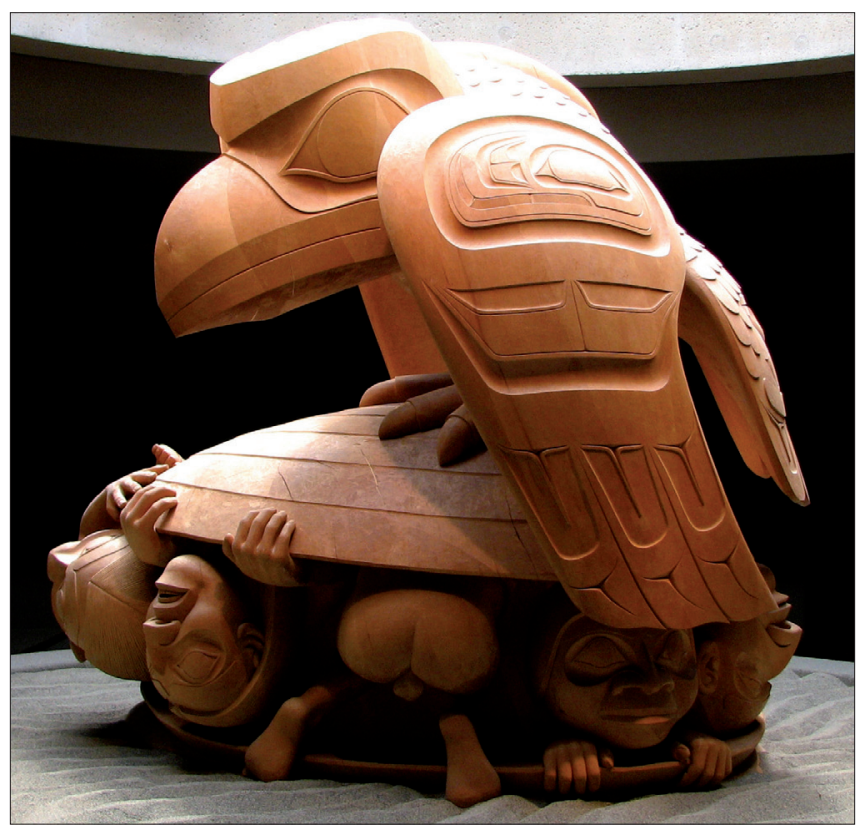

Obr. 15. Havran, Haidové.

představa stoupání duše zemřelého k nebi sférami sedmi planet. Během obřadů nosili zasvěcenci masky, které ilustrovaly jednotlivé stupně. Na rozdíl od pozitivního čísla sedm je v babylonském kalendáři spojován s číslem třináct, jež podporuje jeho negativní význam symbolizací přestupného, třináctého měsíce.

Originálním způsobem vstoupil motiv havrana do středověké alchymistické symboliky, kde byl spojován s procesem transformace hmoty. Zčernání (nigredo) prvotní hmoty (materia prima) v průběhu přeměny $\mathrm{v}$ kámen mudrců bylo interpretováno jako černý havran, který bude při zbělení (albedo) vzkřríšen v podobě bílé holubice.

Zcela unikátní místo zaujímá havran jako mytický a totemový pták v mytologiích, legendách a výtvarném umění indiánských a eskymáckých kultur. Čukčové, Inuité, Korsaci 


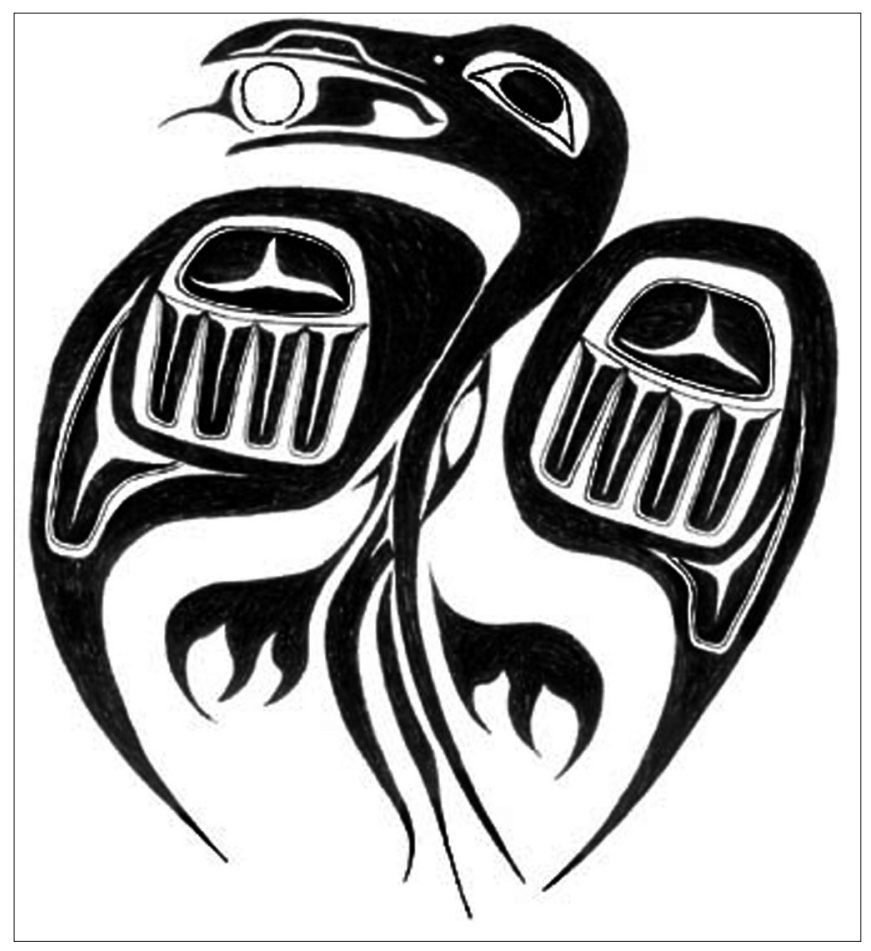

Obr. 16. Havran, který ukradl světlo, Tlingitové.

a indiánské kmeny obývající Severozápadní pobřeží Severní Ameriky (Cimšjanové, Haidové, Kwakiutlové, Sališové, Tlingitové) nebo náhorní plošiny a prérie (Černonožci) považují havrana zpravidla za stvořitele, kulturního hrdinu (trickster) a posvátné zvíře, jehož zabití signalizovalo příchozí neštěstí. Havran nabývá v mýtech indiánských kmenů odlišného pojmenování. Haidy je havran označován Nankil’slas, Cimšjany We-gyet nebo Txamsem, Tlingity Yehl, Kwakiutly Kwekwaxa'we, Tanainy Chulyen, Belabely Hemaskas a Nutky Guguyni. Havran doprovázel mrtvé duše k bráně Smrti, a dokonce mohl být i přísedícím u Velkého Soudu, kde se rozhodovalo o dalším osudu člověka. Indiánští šamani se snažili havrany přilákat ke svým sídlům, nebot jejich peřička používali jako posvátné rituální pomůcky. Motiv havrana, charakteristického rovným a na konci zašpičatělým zobákem, zdobil masky, totemy, kánoe, malby př́bytků, textilie (například pokrývky hlavy a oděvy), měděné a později stř́brné šperky nebo lidské tělo. Například propracovanější formu masek havrana užívala kwakiutlská tajná společnost Hamatsa (obr. 14). Masku charakterizovaly zpravidla rozšířené nozdry, rozevřený zobák, redukce barev na červenou, bílou a černou a zdobení smotanou cedrovou kůrou. V současnosti se významným fenoménem indiánů tichomořského pobřeží Kanady stává umění techniky sítotisku nebo litografie, jejichž prostřednictvím jsou šířeny tradiční motivy a vzory.

Ve většině indiánských mýtů havran ukradl Slunce a Měsíc, stvořil první lidi, vytvořil řeky a jezera a přinesl na zem rostliny a zvírata. Jeho dárcovství ohně a světla je možné považovat za paralelu ke stvořiteli lidského pokolení Títánu Prométheovi, jenž ukradl bohům na Olympu oheň a daroval jej lidem. Podle Haidů z ostrovi̊ královny Charlotty zaslechl havran



Obr. 17. Francouzský malíř a grafik Édouard Manet (1832-1883), ilustrace básně Havran amerického básníka a prozaika Edgara Allana Poea.

na naikunské pláži tlumené zvuky, přicházející z mušle, v níž nalezl lidská novorozeňata (obr. 15).

V dalších indiánských mýtech havran oplodnil dceru Nebeského náčelníka poté, co se proměnil v jehličku konifery. Když náčelníkova dcera nabírala vodu z řeky, spadla jí do nádoby s vodou a při pití ji pak spolkla. Dcera následně porodila syna, jímž byl proměněný havran. V některých mýtech se objevil až po porodu, vyjmul chlapce $z$ kůže a vzal na sebe jeho podobu. Pokud nebylo po chlapcově vůli, propadal záchvatům vzteku. Dědeček, Nebeský náčelník, se mu snažil vyhovět. Nejdříve daroval chlapci krabici s Měsícem, jenž utekl na oblohu. Po dalším vztekání věnoval chlapci druhou krabici, v níž bylo Slunce. Chlapec se nakonec nazpět proměnil v Havrana a unikl otvorem $\mathrm{z}$ náčelníkova domu. Při útěku si zbarvil bílé peří na černé.

Podle Tlingitů stvořilo havrana a volavku (jako dobré a moudré muže nadané nadpřirozenou silou) hlavní božstvo Nazcakiyela, v jehož domě se nacházely slunce, měsíc a hvězdy. Zároveň stvořil i obyčejné lidi, kteří žili ve tmě. Havran se nad nimi slitoval a proměnil se v jehličku konifery, jíž vypila Stvořitelova dcera a otěhotněla. Dítě, které se jí narodilo, dostalo také jméno Havran. Poté co vyrostlo, darovalo lidem vodu, oheň a světlo (obr. 16).

Havran jako šibal je veden honbou za potravou a sexuálním dobrodružstvím. V šibalské roli postrádá morální hodnoty a zpravidla prostřednictvím lstí a triků získává to, co chce. Tento poživačný šprýmař a božský šejdíř, který se může proměňovat v lidské i zvírecí bytosti, zpravidla končí jako potrestaný, podvedený a zahanbený hlupák. Havran jako šibal je falický, nenasytný, lstivý, neřestný, chlípný a hloupý. Např́klad jeho penis dosahuje takové délky, že jej nosí stočený 


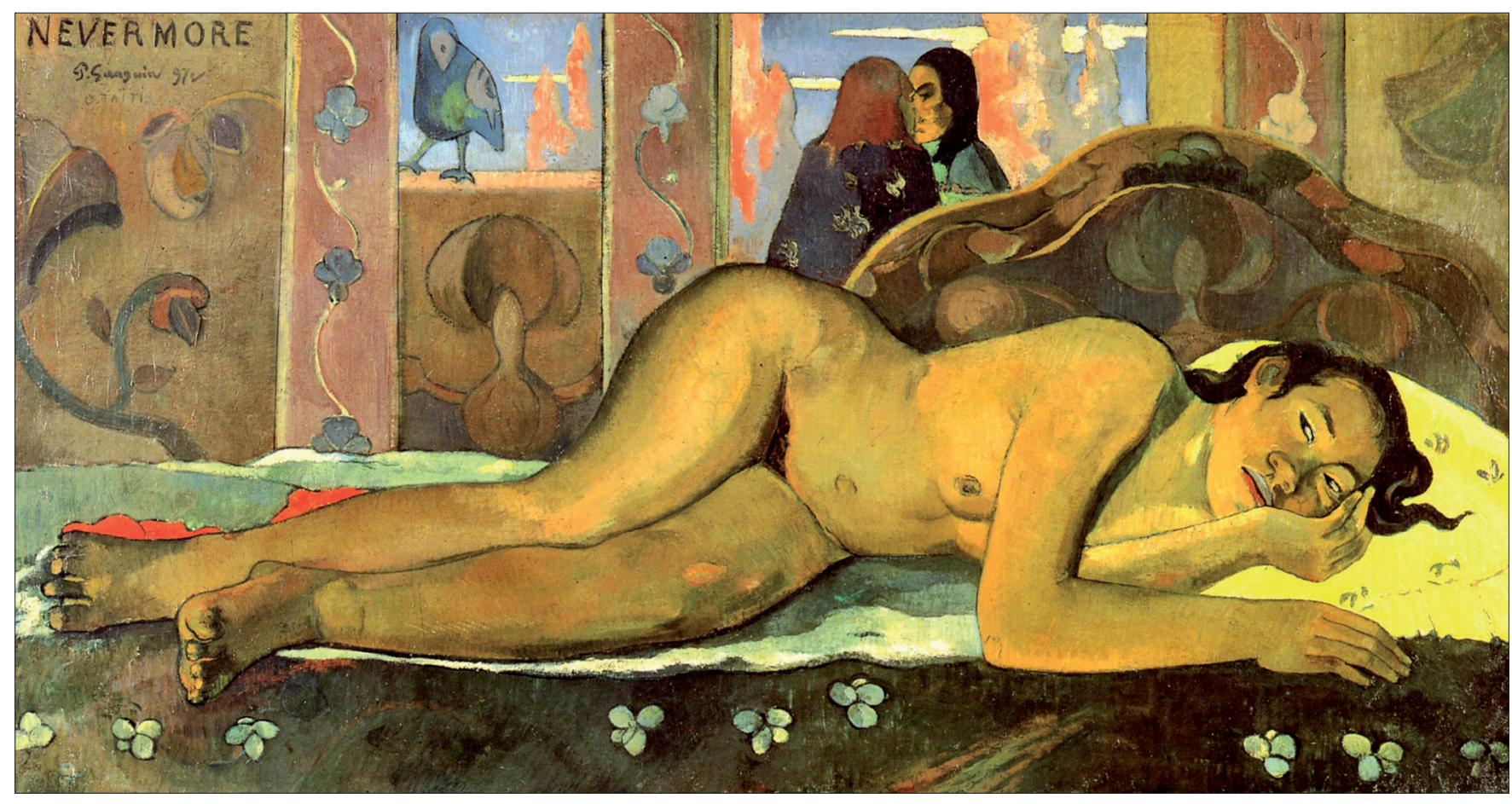

Obr. 18. Francouzský malír Paul Gauguin (1848-1903), olejomalba Nevermore (Už víckrát ne, 1897).

přes rameno. Dokonce ztrácí jednotlivé orgány. Například při krádeži návnady z háčku, pozbude zobák. Havran uspokojuje své choutky, nutkání a nenasytný apetit. Poté, co havran vletěl do útrob velryby, živil se tím, co spolkla. Nakonec jí vyřízl srdce a zabil ji. Moře vyvrhlo její tělo, lidé velrybu rozrrízli a havran ulétl. Ovšem vrátil se a namluvil lidem, že se jedná o zlé znamení. Lidé uposlechli, odešli a havran snědl vše, co zbylo. V evropském kulturním areálu je šibalovi blízký antický hrdina Herkules nebo lišák Renard. Šibal symbolizuje boj člověka se sebou samým a se světem, v němž existuje bez vlastního souhlasu a vůle.

Havran je v mýtech postaven také před různé zkoušky nebo se utkává v souboji. V mýtech Korjaků, žijících na severu poloostrova Kamčatka, musel mytický hrdina Havran unést velmi těžké břemeno. Požádal o pomoc bohy, kteří mu doporučili sníst jedovatou muchomůrku červenou (Amanita muscaria). Havran je uposlechl a nabyl nadlidské síly. Černonožci byl havran pokládán za nejmoudřejšího ptáka. $V$ jednom z mýtů je zaznamenán souboj Havrana a Buřňáka, jejž vyvolal Havran kvůli zimě. Buřňák, pokud nechtěl zmrznout, musel metat blesky. Nakonec však přiznal svou porážku. Podle Čilkatů havran dokonce daroval lidem tabák.

Motiv havrana a s ním spjatá symbolika nezůstala omezena na svět pohádek a mýtů, nýbrž se stala významnou součástí literární, dramatické a výtvarné tvorby. Zejména statečnost a sílu havrana glorifikoval český spisovatel, pedagog a amatérský archeolog Eduard Štorch (1878-1956) v knize Osada Havranů: Přiběh z mladši doby kamenné (1930). O kvalitách havraního rodu promluvil Černý havran (Štorch 1982, 64): „Přesvědčili jste se, že Havran není oškubaná kavka, ale že má silný zobák a ostré drápy (...) Havrani nenaplijí na ruku, kterou v prátelství podáváte."

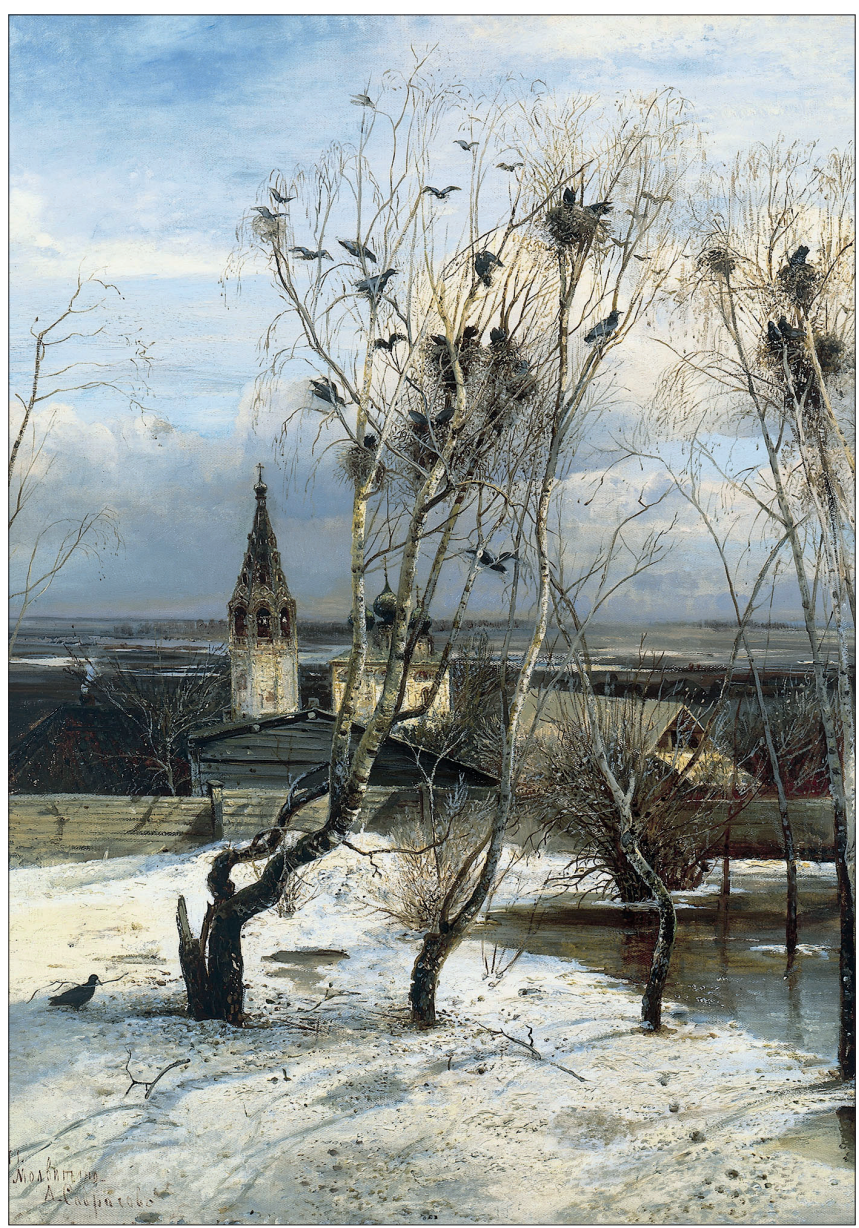

Obr. 19. Ruský malír Aleksej Kondratjevič Savrasov (1830-1897), olejomalba Havrani jsou zpět (1871). 


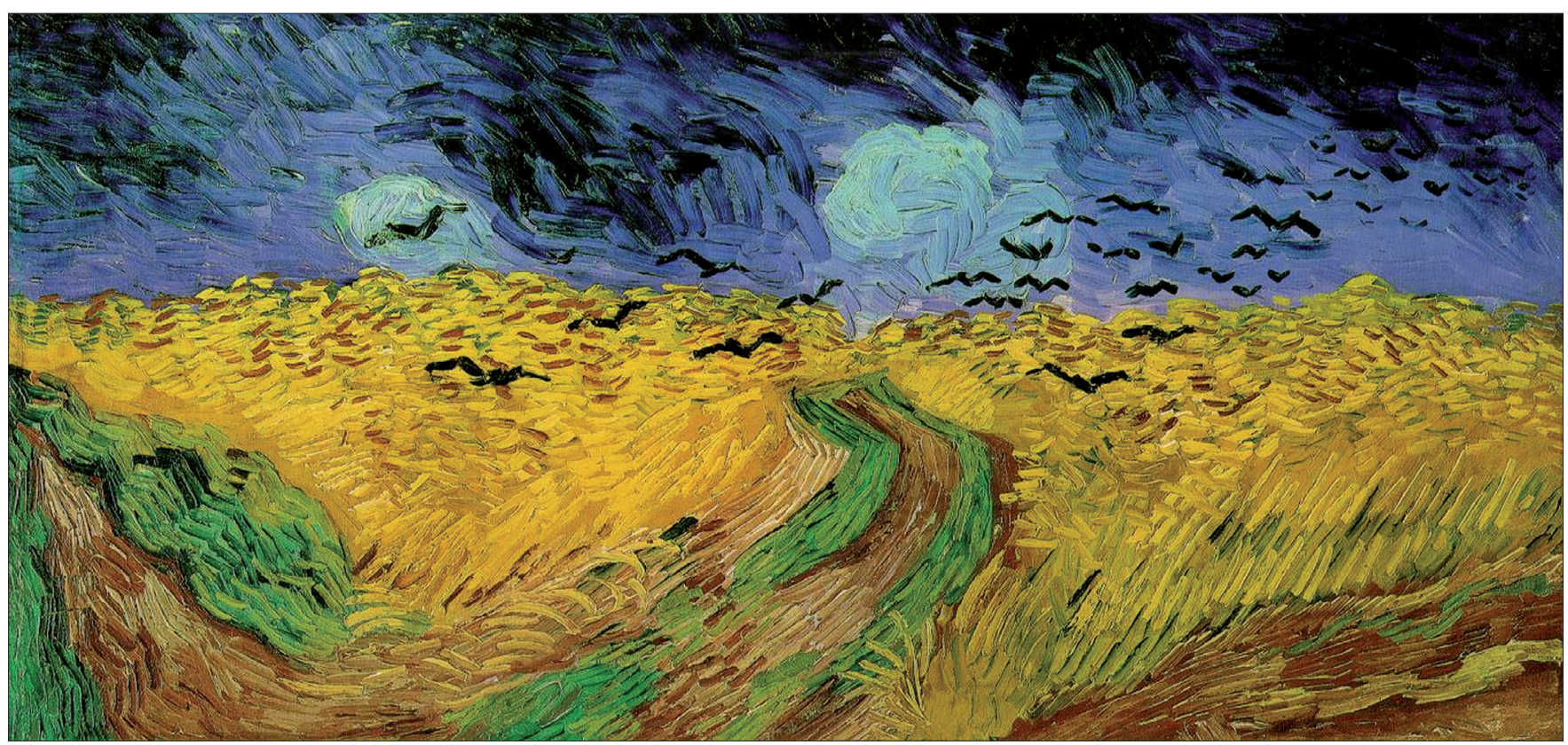

Obr. 20. Nizozemský maliř Vincent van Gogh (1853-1890), olejomalba Havrani nad obilným polem (1890).

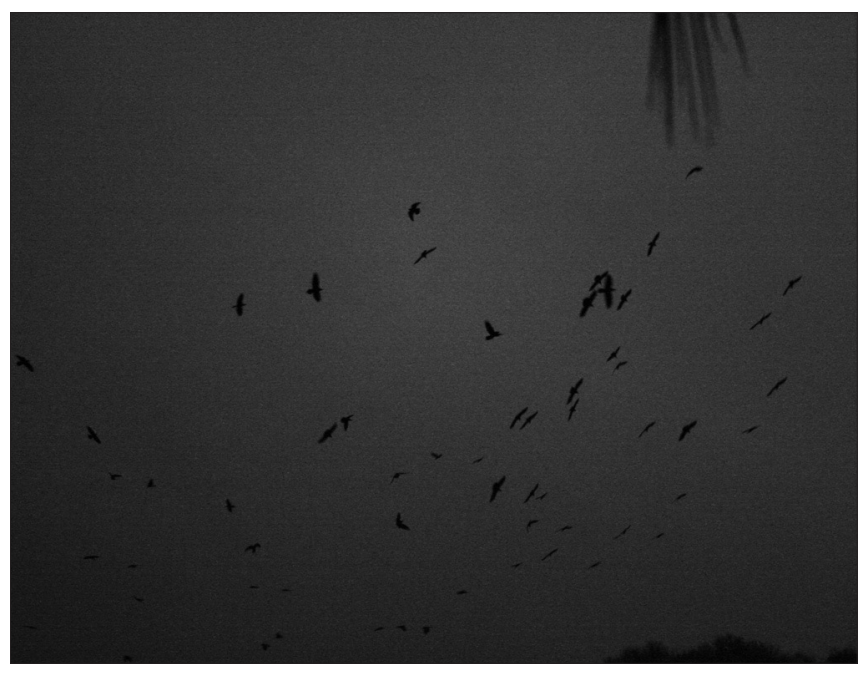

Obr. 21. Japonský fotograf Masahisa Fukase (narozen 1934), černobílá fotografie havranů z knihy Karasu (Havrani, 1986).

Oproti tomu temnou stránku života, spojovanou s havranem, popsal v tragédii Macbeth (Macbeth, kolem 1606, vydáno 1623) anglický dramatik a básník William Shakespeare (1564-1616). Lady Macbeth připravuje vraždu skotského krále Duncana v touze po nástupnictví (Shakespeare 1978, 36): „Sám ten havran chraptí, co kráká, že král Duncan do mých bran se ubírá. Přijdte, vy d’ábli, vraždu co vnukáte! Mé ženskosti mě zbavte a od hlavy až k patě nejkrutější mě naplňujte zlostí!"

Zabití havrana jako symbolu přicházejícího prokletí ztvárnil italský dramatik Carlo Gozzi (1720-1806) v díle Il Corvo (Havran, 1761). Během lovu král Millo proklál havrana šípem. Tělo ptáka spadlo na bílou desku mramorového pomníku,

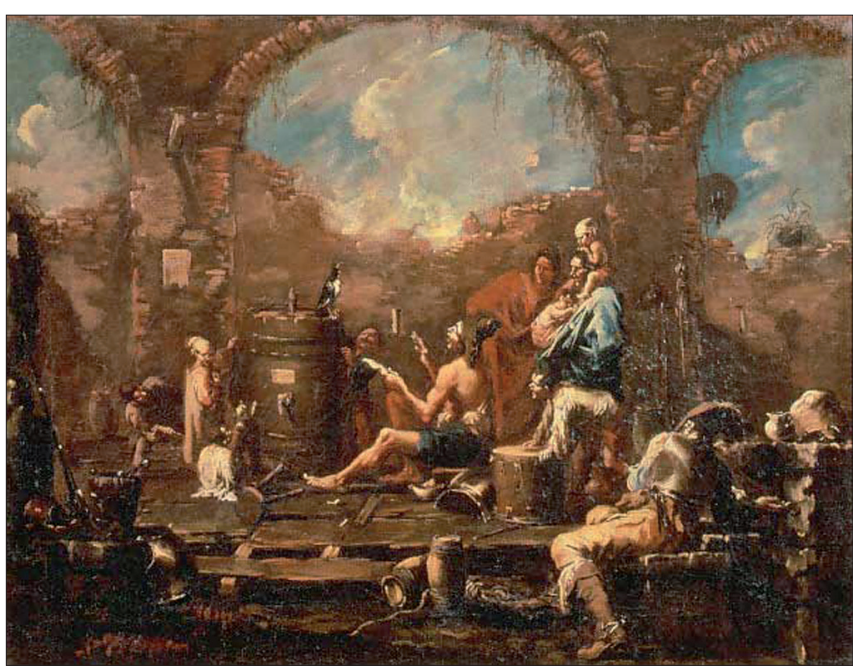

Obr. 22. Italský malír Alessandro Magnasco (1667-1749), olejomalba Moudrý havran (1703-1711).

kterou potřísnilo krví. V rozšuměném lese vystoupil netvor, jenž pronesl prokletí (Gozzi 1932, 6):

„Věz, dokud nenajdeš tu $z$ žen,

jež bilá je jak mramor ten, jak havraní krev líce rudé, šlenstvím údělem ti bude až v zuřivosti zlomís vaz."

Nesmrtelnou slávu získal temný motiv havrana americkému básníkovi a prozaikovi Edgaru Allanu Poeovi (1809-1849), který jej zpracoval v básni The Raven (Havran, 1845). Hlavní hrdina básně, muž zlomený bolestí ze smrti milované ženy, se 


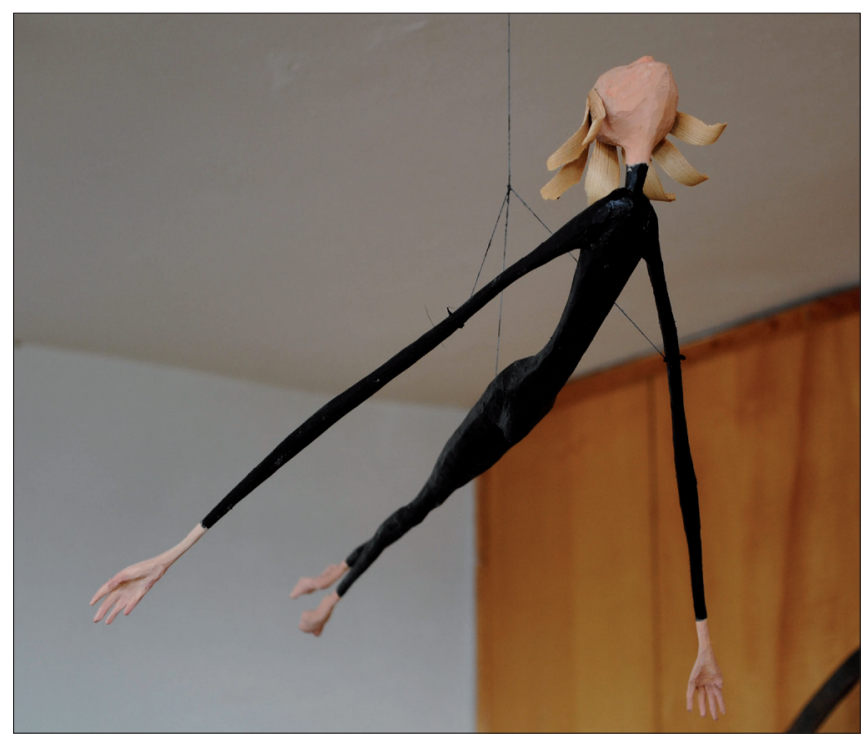

Obr. 23. Český sochař Zdeněk Macháček (narozen 1925), Havran Yára (2010, smrk [vlasy], vrba [hlava], tělo [topol], délka $73,5 \mathrm{~cm}$ ).

Foto: Tomáš Mořkovský

skrývá před vnějším světem. Sedí v pokoji, který byl útočištěm jeho schůzek s mrtvou Lenorou, a snaží se nad knihou zapomenout na svou bolest. Havran, ztotožněný s prorokem, symbolem zla a sebetrýzně, se usadí na bělostném poprsí mramorové busty Pallas Athény. Muž chce vědět, zda nalezne po smrti vytoužený klid a ještě někdy spatří Lenoru. Havran na všechny otázky odpovídá lakonickým: „už víckrát ne“ (Poe 1959, 37).

„Tos řek jistě na znamení, že se chystáš k rozloučení, táhni zpátky do bouře a do podsvětí, satane! Nenech mi tu, starý lhárí, ani pirka na polštárí, neruš pokoj mého stárí, opust' sochu, havrane! Vyndej zobák z mého srdce, opust' sochu, havrane!" Havran dí: „Už víckrát ne.“

Vydání básně Havran ilustrovali francouzští malíri a grafici Gustav Doré (1832-1883), Édouard Manet (1832-1883) (obr. 17), Odilon Redon (1840-1916) a Edmund Dulac (18821953) nebo britský ilustrátor a karikaturista John Tenniel (1820-1914). České překlady doprovodily ilustrace malírư a grafiků, jimiž byli např́iklad František Kobliha (1877-1962), Jan Konůpek (1883-1950), František Tichý (1896-1961), Pavel Sukdolák (narozen 1925) nebo Pavel Růt (narozen 1967). Motiv a symbolika havrana pronikly do celé řady moderních výtvarných děl. Například touhu po zapomnění a potlačení vzpomínek, inspirovanou básní Havran, vyjádřil v olejomalbě Nevermore (Už víckrát ne, 1897) francouzský malír Paul Gauguin (1848-1903). Jedná se o akt mladé ženy, která je zachycena ve stavu hlubokého duševního otřesu a psychické trýzně, již potvrzuje nejenom prázdnota jejích očí a dvě šeptající ženy na pozadí plátna, nýbrž i černý havran (obr. 18). Cyklický zánik př́rody navozuje plátno Havrani jsou zpět (1871), jehož autorem je ruský malír Aleksej Kondratjevič Savrasov (18301897). Havrani a jejich hnízda jsou zde ztvárněni v holých

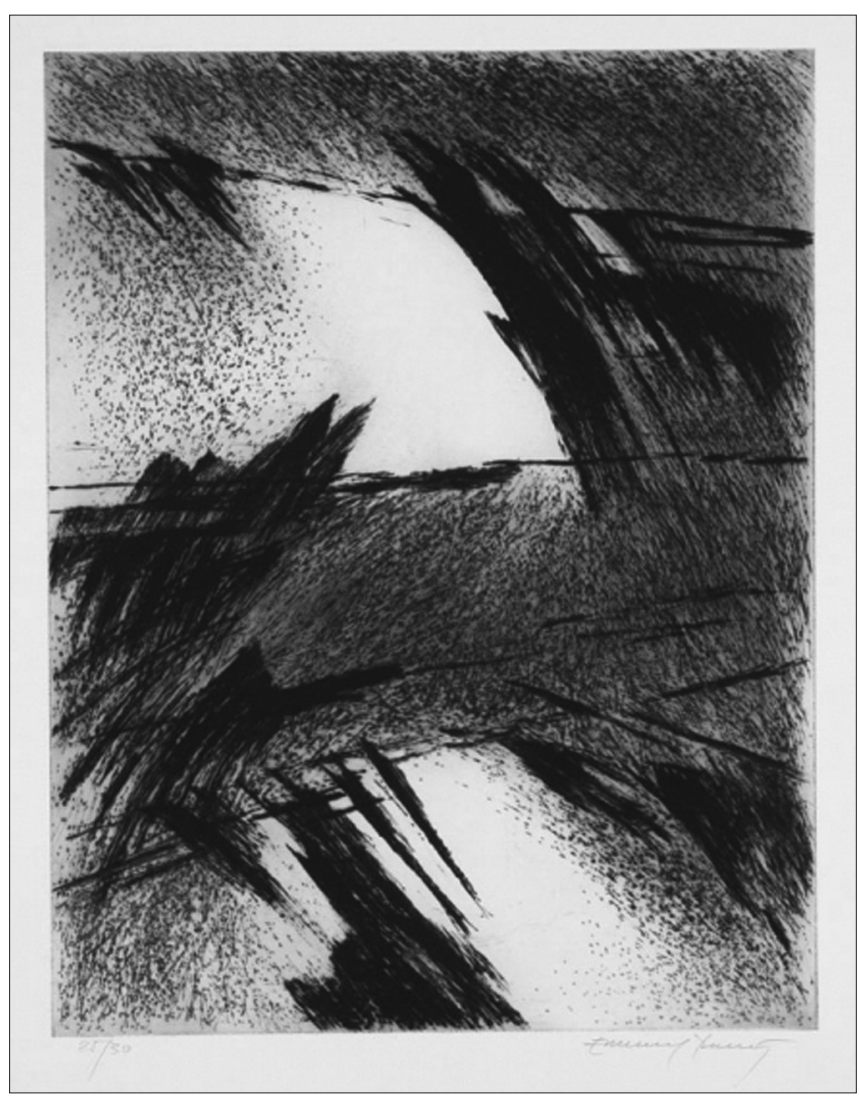

Obr. 24. Český malíř a grafik Emanuel Ranný (1913-2008), suchá jehla Havraní krajina III. (1992, 50x39cm).

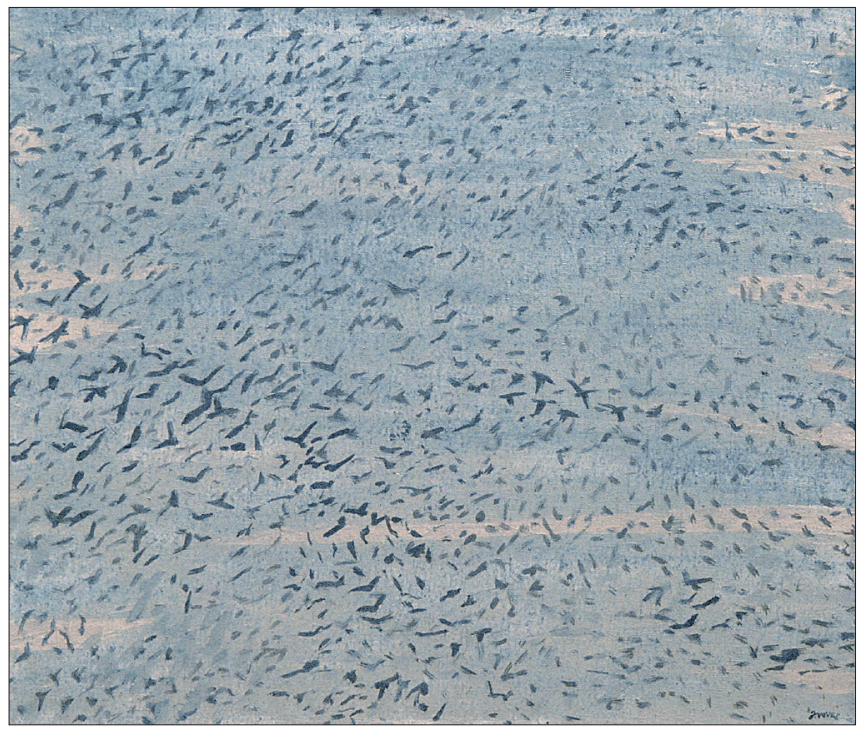

Obr. 25. Český malír Jiří Voves (narozen 1945), z cyklu Havrani (2009, plátno, tmel, akryl, olej, $60 \times 70 \mathrm{~cm})$.

korunách stromů nad zasněženou vesnicí (obr. 19). Lidský život směřující k zániku a zmaru symbolizují i letící havrani na olejomalbě Havrani nad obilným polem (1890), kterou vytvořil nizozemský malír Vincent van Gogh (1853-1890) ve stavu těžké duševní deprese (obr. 20). Na sklonku života maloval krajinu v okolí Auvers, obilná pole, mohutné cypřiše, 




Obr. 26. Česká výtvarnice Stáňa Bártová (narozena 1952), z nekonečného cyklu Navždy uhranutá havrany (2007, fotografie).

noční oblohu nebo tisíce havranů, mávajících křídly, jež mu posloužily jako inspirační zdroj ke vzniku tohoto plátna (Stone 2009, 430-431): „Kolem poledne, když mu prudké slunce pražilo nad hlavu, snesl se náhle z oblohy nálet černých ptáků. Naplnili vzduch, zatmèli slunce, hodili na Vincenta tlustou přikrývku noci, létali mu do vlasů, do očí, do nosu, do úst, pohřbili ho $v$ černém dusivě neprodyšném mraku mávajících kř́del." Existenciální a meditativní dimenzi obsahují černobílé fotografie havranů v knize Karasu (Havrani, 1986), jež zachytil japonský fotograf Masahisa Fukase (narozen 1934) (obr. 21). S destrukcí idylického života se setkáváme také v olejomalbě Moudrý havran (1703-1711), kterou vytvořil italský maliř Alessandro Magnasco (1667-1749). Na obraze je uprostřed antických ruin zobrazen dav lidí obklopující havrana stojícího na vinném sudu, před nímž sedí předčítající muž. Poselství jeho slov podtrhuje zmar, hniloba a trouchnivění okolního exteriéru i šílenství obsažené v očích přihlížejících (obr. 22). Díla, inspirovaná symbolikou havrana, vytvořili i čeští výtvarníci sochař Zdeněk Macháček (1925), malíŕi a grafici Emanuel Ranný (1913-2008) a Jiří Voves (narozen 1945) nebo grafička a fotografka Stáňa Bártová (narozena 1952) (obr. 23-26). Temnému motivu havrana neodolal ani německý hudební skladatel Richard Wagner (1813-1883) a využil jeho symboliku ve čtvrté části série oper Der Ring des Nibelungen (Prsten Nibelungů) - Götterdämmerung (Soumrak bohů, 1848-1874). Havrani zde zakrouží nad Siegfriedem a odletí. Poté Hagen zavraždí Siegfrieda, nebot' mu havrani poradili pomstu.
Expanze fenoménu havran se nevyhnula ani moderní vědě. Svědčí o tom např́iklad dílo amerického filozofa německého původu Carla Gustava Hempela (1905-1997). Hempel formuloval tzv. "havraní paradox“, jehož prostřednictvím testoval, jak dalece induktivní logika směřuje $\mathrm{k}$ odhalení pravdivého závěru. Paradox a tajemství lidského osudu obsahuje rozhlasová hra Herrn Walsers Raben (Havrani pana Walsera, 1959, premiéra 1960), jejímž autorem je německý spisovatel a malír Wolfgang Hildesheimer (1916-1991). Havrani pana Adriána Walsera, kteři krákají na zahradě, jsou jeho proměnění příbuzní a prátelé. Vyslovení kouzelné formulky představuje nevratný experiment, kdy se lidský jedinec navždy stane havranem, dalším černošedým opeřeným členem ptačího hejna. To je neodolatelným předmětem pozorování pana Walsera, zejména v průběhu zimního období (Hildesheimer 1965, 87): „Víte, miluju zimu, třpytnou běl na stř́šce pergoly. Pískovcového Apolona se sněhovou čapkou. A mí havrani - v zimě mi připadají, jako by nebyli z tohoto světa, natož pak z mého - nezdá se vám to taky? Ještě nikdy jsem o tom nepřemýšlela. Ovšemže ne. Vy taky nemáte zapotřebí přemýšlet o havranech. Ano ano - musí to být krásné mít čisté svědomi."

Havrana vyjadřujícího paradox postmoderní společnosti ztvárnil český umělec Krištof Kintera (narozen 1973) jako součást instalace I see, I see, I see (Vidím, vidím, vidím, 2009). Havrana oblékl do černé košile, pánských kalhot a polobotek (obr. 27). Na větev, kde pták sedí, umístil také koženou bundu. Havran svým krákavým hlasem vede monolog, kroutí 




Obr. 27. Český umělec Krištof Kintera (narozen 1973), postmoderní Havran.

hlavou a kývá nohama nad hlavami procházejících lidských bytostí: „That's problem. Fucking problem“ (To je problém, posraný problém). Navzdory řezavému smíchu, pod nímž se prohýbá větev, havran dodává: „It is not funny, not funny“ (To není zábavné, není zábavné).

Setkání s postmoderním havranem ve výstavní síni zcela symbolicky završuje dlouhou pout', kterou tento pták v průběhu své existence absolvoval. Literární, výtvarné a symbolické proměny havrana $\mathrm{v}$ různých světových kulturách a historických obdobích svědčí o kulturní nadčasovosti „fenoménu havran“ a naznačují, že tento pták reprezentuje jeden z univerzálních lidských archetypů. Jedná se o archetyp stínu - představy švýcarského psychologa Carla Gustava Junga (1875-1961) o zahaleném zdroji zla a dědictví zvírecího elementu. Stín tvoří skryté, nevědomé a temné obsahy naší osobnosti. Stín lze označit za negativní a vytěsněné myšlení, jež nás doprovází stejně jako stín našeho těla (Jung 1995, 181): „Každého doprovází ,stín, a o co méně je tento stín vtělen do vědomého života jedince, tím je černější a hutnější." Stín provokuje a zároveň děsí, nebot’ zahrnuje agresivitu, závist, nenávist, chamtivost, proradnost nebo i sobectví - živočišné, neodbytné a všudypř́ítomné vlastnosti naší osobnosti, z jejichž uzavřeného kruhu nelze uniknout.

Tento článek byl napsán pro připravovanou knihu Stáni Bártové Uhranutá havrany (Brno: Akademické nakladatelství CERM, 2012).

\section{LITERATURA}

Aisópos (1975): Ezopovy bajky. Praha: Mladá fronta.

Balabán, Milan - Tydlitátová, Věra (2002): Gilgameš: Mytické drama o hledání věčného života. Praha: Vyšehrad.

Barber, Richard (2006): Bestiary: Being an English Version of the Bodleian Library, Oxford MS Bodley 764. Woodbridge: Boydell Press.

Béowulf (2003): Praha: Argo.

Blackstock, Michael D. (2001): Faces in the Forest: First Nations Art Created on Living Trees. Montreal: McGill-Queen's University Press.

Cicero, Marcus Tullius (1996): Předtuchy a výstrahy. Olomouc: Votobia.

Claretus (1991): Ptačí zahrádka. Brno: Petrov.

Dvořáková, Nina - Malina, Jaroslav (2005): Zdeněk Macháček. Brno: Akademické nakladatelství CERM.

Edmondsová, Margot - Clarková, Ella (2000): Hlasy větrů: Mýty severoamerických Indiánů. Praha: Nakladatelství Lidové noviny.

Edda (1962): Praha: Státní nakladatelství krásné literatury, hudby a umění.

Epos o Gilgamešovi (1958): Praha: Státní nakladatelství krásné literatury, hudby a umění

Emmons, George T. (1991): The Tlingit Indians. Seattle: University of Washington Press.

Fornari, Bruno (2006): Das Theater der Grausamkeit von Rops bis Kubin. In Assmann, Peter: Obsessions. Weitra: Bibliothek der Provinz.

Gozzi, Carlo (1932): Havran: Tragikomická pohádka o pěti jednáních. Smíchov: Vaněk a Votava.

Greenová, Miranda Jane (1998): Keltské mýty. Praha: Nakladatelství Lidové noviny.

Guter, Josef (2005): Bohové a symboly Staré Číny: Sborník čínské mytologie. Praha: Nakladatelství Brána.

Hawthorn, Audrey (1967): Art of the Kwakiutl and the Other Northwest Coast Tribes. Seattle: University of Washington Press.

Hildesheimer, Wolfgang (1965): Havrani pana Walsera. In: Divadlo, roč. 16, s. $86-96$.

Horák, Jiří (1998): Oheň na sněhu: Mýty sibiřských lovců. Praha: Argo.

Isidor ze Sevilly (2004): Etymologiae XII. - Etymologie XII. Praha: Oikoymenh.

Jung, Carl Gustav (1995): Člověk a duše. Praha: Academia.

Jung, Carl Gustav (1999): Výbor z díla II.: Archetypy a nevědomí. Brno: Nakladatelství Tomáše Janečka.

Kadečková, Helena (1997): Dějiny severských literatur I.: středověk. Praha: Karolinum

Klápštová, Kateřina - Larink, Walter - Streum, Ralf (2009): Krkavec, Kosatka, Žába, Buřnák: Současné umění Indiánu tichomořského pobřeží Kanady. Praha: Velvyslanectví Kanady v Praze.

Kolář, Jiří (1957): Ezop \& Hollar. Bajky. Praha: Naše vojsko.

Lévi-Strauss, Claude (2006): Mythologica: Od medu k popelu. Praha: Argo.

Lévi-Strauss, Claude (2007): Strukturální antropologie II. Praha: Argo.

Lurker, Manfred (2005): Slovník symbolů. Praha: Knižní klub.

Malina, Jaroslav a kolektiv (2009): Antropologický slovník aneb co by mohl o člověku vědět každý člověk ( $s$ prihlédnutím $k$ dějinám literatury a umění). Brno: Akademické nakladatelství CERM.

Malina, Jaroslav - Zvěřina, Jaroslav (2008): Erotikon sochaře Zdeňka Macháčka. Brno: Akademické nakladatelství CERM.

Olbracht, Ivan (1972): O mudrci Bidpajovi a jeho zvírátkách. Praha: Albatros.

Ovidius Naso, Publius (1958): Proměny. Praha: Státní nakladatelství krásné literatury, hudby a umění.

Plinius Secundus, Gaius (1974): Kapitoly o prírodě. Praha: Svoboda.

Poe, Edgar Allan (1959): Havran. Praha: Mladá fronta.

Pospiszyl, Tomáš (2005): Krištof Kintera 730920/0184. Katalog 95-05. Praha: Divus \& Makum.

Prosecký, Jiří et al. (2003): Encyklopedie starověkého Předního Východu. Praha: Libri.

Radin, Paul - Kerényi, Karl - Jung, Carl Gustav (2005): Trickster: Mýtus o Šibalovi. Indiánský mýtus v kontextu světových mytologií. Praha: Dobra.

Riese, Brigitte (2007): Seemanns Lexikon der Ikonografie. Religiöse und profane Bildmotive. Leipzig: E. A. Seemann.

Rouir, Eugène (1992): Félicien Rops: Catalogue Raisonné de l'Euvre Gravé et Lithographié II. Bruxelles: Claude Van Loock.

Royt, Jan - Šedinová, Hana (1998): Slovník symbolů: Kosmos, příroda a člověk $v$ křestanské ikonografii. Praha: Mladá fronta.

Shakespeare, William (1978): Mackbeth. Praha: Odeon.

Stone, Irving (2009): Žízeň po životě. Praha: BBart.

Štorch, Eduard (1982): Osada Havranů: Př́běh z mladši doby kamenné. Praha: Albatros.

Tolkien, John Ronald Reuel (1979): Hobit aneb cesta tam a zase zpátky. Praha: Odeon.

Wagner, Richard (2002): Prsten Nibelungův. Praha: Státní opera Praha.

Zelený, Mnislav (1994): Indiánská encyklopedie: Indiáni tř́ Amerik. Praha: Albatros. 


\section{AUTORKA}

Půtová, Barbora (14. 11. 1985, Praha), česká kulturoložka a historička umění; doktorandka na Katedře teorie kultury (kulturologie) a Ústavu pro dějiny umění Filozofické fakulty Univerzity Karlovy v Praze. Předmětem jejího vědecko-výzkumného zájmu jsou dějiny kultury, pravěké umění a umělecké směry symbolismus a dekadence. Pozornost věnuje také fenoménu knižní kultury, problematice středověkých iluminovaných rukopisů, středověké ikonografii, historické a postmoderní antropologii. Dlouhodobě se zabývá studiem grafických, tiskových, kresebných a malîrských technik. Ve svých přednáškách integruje znalosti z dějin kultury, kulturní antropologie, českého a světového umění, literatury i hudby do komplexní- ho celku. Průběžně publikuje studie a články věnované osobnosti a uměleckému dílu belgického malíre a ilustrátora Féliciena Ropse. Je autorkou učebnice Evoluce člověka a pravěké umění (2010) a připravuje knihu Dějiny kultury (2011), na jejichž spoluautorství se podílí český kulturní antropolog a kulturolog Václav Soukup. Diplomová práce: Kulturní dimenze symbolů jako replikátorů informací: Mediátory kultury v čase a prostoru (2009); rigorózní práce: Memy jako nástroje replikace umèní (2010); názvy připravovaných disertačních prácí: Pravěké umění (2011) a Félicien Rops v kontextu své tvorby a doby (2012).

Kontakt: PhDr. Barbora Půtová, Katedra teorie kultury (kulturologie) Filozofické fakulty Univerzity Karlovy v Praze, Celetná 20, 11000 Praha 1, e-mail: bonthyl@email.cz. 